\title{
REVIEW
}

\section{REGULATION OF AMPA RECEPTORS AND SYNAPTIC PLASTICITY}

\author{
S. D. SANTOS, A. L. CARVALHO, M. V. CALDEIRA \\ AND C. B. DUARTE* \\ Center for Neuroscience and Cell Biology, Department of Zoology, \\ University of Coimbra, 3004-517 Coimbra, Portugal
}

\begin{abstract}
Neuronal activity controls the strength of excitatory synapses by mechanisms that include changes in the postsynaptic responses mediated by AMPA receptors. These receptors account for most fast responses at excitatory synapses of the CNS, and their activity is regulated by various signaling pathways which control the electrophysiological properties of AMPA receptors and their interaction with numerous intracellular regulatory proteins. AMPA receptor phosphorylation/dephosphorylation and interaction with other proteins control their recycling and localization to defined postsynaptic sites, thereby regulating the strength of the synapse. This review focuses on recent advances in the understanding of the molecular mechanisms of regulation of AMPA receptors, and the implications in synaptic plasticity. (C) 2008 IBRO. Published by Elsevier Ltd. All rights reserved.
\end{abstract}

Key words: long-term potentiation, long-term depression, glutamate, receptor trafficking, receptor phosphorylation.

Expression of AMPARs

Contents

AMPAR structure and diversity

AMPAR post-translational modifications

AMPAR traffic

AMPAR biosynthesis and AMPAR interaction partners

AMPAR regulation by cell adhesion molecules (CAMs)

*Corresponding author. Tel: +351-239-480209; fax: +351-239-480208. E-mail address: cbduarte@ci.uc.pt (C. B. Duarte).

Abbreviations: ABP, AMPA receptor-binding protein; AMPAR, AMPA receptor; Arc, activity-regulated cytoskeleton-associated protein; $A \beta$, beta-amyloid; BAR, Bin/amphyphysin/Rvs; BDNF, brain-derived neurotrophic factor; CAM, cell adhesion molecule; $\mathrm{CaMKII}, \mathrm{Ca}^{2+}$ - and calmodulin-dependent protein kinase II; cGKII, cGMP-dependent protein kinase II; CNQX, 6-cyano-7-nitroquinoxaline-2,3-dione; ER, endoplasmic reticulum; ERK, extracellular signal-regulated kinase; FRAP, fluorescence recovery after photobleaching; GFP, green-fluorescent protein; GluR $\delta 2, \delta 2$ glutamate receptor; GRIP, glutamate receptor interacting protein; LBD, ligand-binding domain; LTD, long-term depression; LTP, long-term potentiation; MAGUK, membrane-associated guanylate kinase; MAPK, mitogen-activated protein kinase; mEPSC, miniature excitatory postsynaptic current; mGluRs, metabotropic glutamate receptors; Narp, neuronal-activity-regulated pentraxin; NCAM, neural cell adhesion molecule; NMDA, $N$-methyl-D-aspartate; NMDAR, $N$-methyl-D-aspartate receptor; NPR, neuronal pentraxin receptor; NPRAP, neural plakophilin-related arm protein; NP1, neuronal pentraxin 1; PDZ, postsynaptic density 95/disc large/zonula occludens-1; PICK1, protein interacting with C-kinase-1; PI3-K, phosphatidylinositol 3-kinase; PKA, protein kinase A; PKC, protein kinase C; PSA, polysialic acid; PSD, postsynaptic density; SEP, superecliptic pHluorin; Ser, serine; SNARE, soluble $\mathrm{N}$-ethylmaleimide-sensitive factor attachment protein receptors; TARP, transmembrane AMPA receptor regulatory proteins; TM, transmembrane; TNF $\alpha$, tumor necrosis factor- $\alpha$.

\author{
Vesicular traffic, synaptic targeting and lateral membrane \\ diffusion of AMPARs \\ AMPAR phosphorylation and trafficking in synaptic plasticity \\ Role of AMPARs in LTP \\ Role of AMPARs in LTD \\ Hippocampal LTD \\ Cerebellar LTD \\ AMPARs in homeostatic plasticity \\ Conclusion \\ Acknowledgments \\ References

Glutamate is the major excitatory neurotransmitter in the brain, and its effects are mediated by activation of ionotropic and metabotropic receptors, differing in their molecular, biochemical pharmacological and physiological properties (Hollmann and Heinemann, 1994; Kew and Kemp, 2005). The ionotropic glutamate receptors have been classified into three major subtypes, AMPA, kainate, and $\mathrm{N}$-methyl-D-aspartate (NMDA) receptors, named after their most selective agonist (Watkins et al., 1981). AMPA receptors (AMPARs) are responsible for the primary depolarization in glutamate-mediated neurotransmission and play key roles in synaptic plasticity. Long-lasting and activity-dependent changes in synaptic strength (long-term potentiation, LTP, or long-term depression, LTD) are associated with changes in the phosphorylation and cellular distribution of AMPAR, and are thought to underlie learning and memory formation (Rumpel et al., 2005; Morris, 2006; Pastalkova et al., 2006; Whitlock et al., 2006). Deregulation of AMPAR activity is also involved in pathology [e.g. (Kwak and Weiss, 2006; Liu et al., 2006)]. This review will concentrate on the molecular mechanisms of regulation of AMPARs, and their implications in synaptic plasticity.

\section{EXPRESSION OF AMPARS}

AMPARs consist of four closely related genes, with about $70 \%$ sequence homology (Collingridge et al., 2004), that encode the four subunits GluR1-4 or A-D (Laube et al., 1998; Mano and Teichberg, 1998; Rosenmund et al., 1998). In situ hybridization studies, receptor autoradiography using $\left[{ }^{3} \mathrm{H}\right] \mathrm{AMPA}$ and $\left[{ }^{3} \mathrm{H}\right]$ glutamate as ligands, and immunocytochemistry with antibodies raised against GluR1-GluR4 subunits [reviewed in (Hollmann and Heinemann, 1994; Petralia et al., 1999)] showed a widespread distribution of AMPARs in the brain, as expected from their key role in excitatory neurotransmission. GluR1-GluR3 subunits are enriched in the outer layers of the cerebral cortex, hippocampus, olfactory regions, basal ganglia, lateral septum and amygdala (Kein- 
anen et al., 1990; Beneyto and Meador-Woodruff, 2004). The GluR4 subunit is present in lower amounts throughout the CNS, except in the reticular thalamic nuclei and the cerebellum, where this subunit is also abundant (Petralia and Wenthold, 1992; Martin et al., 1993; Spreafico et al., 1994). The expression of AMPAR subunits is also differentially regulated during development (Petralia et al., 1999; Palmer et al., 2005b; Talos et al., 2006), and although they are regarded as neuronal receptors, they have also been detected in glial cells (Gallo and Russell, 1995; Janssens and Lesage, 2001; Lin and Bergles, 2004).

A recent study using quantitative fluorescence in situ hybridization demonstrated that endogenous mRNAs encoding AMPAR subunits GluR1 and GluR2 are localized to proximal and distal dendrites of hippocampal neurons and that a substantial fraction of synaptic sites contain GluR2 mRNA clusters (Grooms et al., 2006). The presence in dendrites of the machinery necessary for protein synthesis, together with the mRNA for AMPAR subunits, suggests that local synthesis of AMPAR subunits regulates local receptor abundance and composition (Steward and Levy, 1982; Kacharmina et al., 2000; Tang and Schuman, 2002; Asaki et al., 2003; Ju et al., 2004; Grooms et al., 2006). Accordingly, chronic activity blockade increases the synthesis of GluR1 in dendrites, and acute activation of group I metabotropic glutamate receptors (mGluRs) or acute depolarization with $\mathrm{KCl}$ increases the synthesis of both GluR1 and GluR2 (Ju et al., 2004). Also, dopamine receptor activation promotes transport of endogenous mRNAs, including those from GluR1 and GluR2 in hippocampal neurons (Smith et al., 2005). Interestingly, in situ hybridization studies also demonstrate the presence of mRNA encoding proteins relevant in the regulation of the excitatory synapses, such as microtubule-associated protein 2 (MAP2), the $\alpha$-subunit of $\mathrm{Ca}^{2+}$ - and calmodulin-dependent protein kinase II (CaMKII- $\alpha)$, brain-derived neurotrophic factor (BDNF), activity-regulated cytoskeleton-associated protein (Arc), TrkB receptor, inositol-1,4,5trisphosphate $\left(\operatorname{Ins}(1,4,5) \mathrm{P}_{3}\right)$ receptor, the atypical protein kinase $\mathrm{M} \zeta$, the NMDA receptor (NMDAR) NR1 subunit, and glycine receptor $\alpha$ subunit in dendritic layers of hippocampus and in dendrites of hippocampal neurons in vivo and in vitro [for reviews, see (Martin and Zukin, 2006; Schuman et al., 2006)]. Localization of mRNAs and regulated translation in dendrites have recently gained widespread acceptance as mechanisms fundamental to synaptic plasticity (Eberwine et al., 2001; Steward and Schuman, 2003; Martin and Zukin, 2006; Schuman et al., 2006).

\section{AMPAR STRUCTURE AND DIVERSITY}

AMPARs are largely $\mathrm{Ca}^{2+}$-impermeable, display exceptionally fast kinetics and mediate moment-to-moment synaptic signaling (Jonas, 2000). These characteristic functional properties depend on the subunit composition and on subunit modifications introduced by alternative splicing.

The AMPAR GluR1-GluR4 subunits combine in tetramers in different stoichiometries (Hollmann and Heinemann, 1994), which determine channel function (i.e. desensitization/resensitization kinetics and conductance properties) (Ozawa et al., 1998) and trafficking to synapses (Malinow et al., 2000). Stargazin and other transmembrane (TM) AMPA receptor regulatory proteins (TARPs) also coassemble stoichiometrically with native AMPARs. The TARPs act as auxiliary subunits that are required for AMPAR maturation and trafficking, and modulate channel function (see below) (Korber et al., 2007; Ziff, 2007).

Each AMPAR subunit comprises about 900 amino acids and has a molecular weight of about $105 \mathrm{kDa}$. The GluR1-GluR4 subunits share $68-74 \%$ amino acid sequence identity (Collingridge et al., 2004) and contain four hydrophobic domains: TM1, TM3, and TM4 transverse the membrane, while $\mathrm{M} 2$ faces the cytoplasm as a reentered loop that forms part of the channel pore (Fig. 1A). The $\mathrm{N}$-terminal segment is homologous to the bacterial leucineisoleucine-valine binding protein (LIVBP), while the adjacent ligand-binding domain (LBD) is homologous to glutamine binding protein (Madden, 2002). The LBD is split into the $\mathrm{S} 1$ and $\mathrm{S} 2$ segments by TM segments. Ligand binding to the LBD initiates conformational changes that are transduced to the TM segments and trigger opening of the channel's gate (Gouaux, 2004; Mayer, 2005). All three modules - the N-terminus, the LBD, and the ion-channel domain-are engaged in distinct, interdependent subunitsubunit interactions (Greger et al., 2006). The C-terminal part of S2 is not directly involved in agonist binding and, due to alternative RNA splicing, is expressed in two forms, flip and flop, that differ in a few amino acids only, but which result in receptors with different desensitization and endoplasmic reticulum (ER) export kinetics (Sommer et al., 1990; Mosbacher et al., 1994; Coleman et al., 2006). A recent study from our laboratory identified versions of the AMPAR subunits that lack both the flip and flop exons, and play a dominant negative role (Gomes et al., 2007b).

Finally, the C-terminus of AMPAR subunits is intracellular and shows differences between the subunits. GluR1, GluR4, and an alternative splice form of GluR2 (GluR2L) have longer cytoplasmic tails with high homology (Fig. 1B). In contrast, the predominant splice form of GluR2, GluR3, and an alternative splice form of GluR4 (GluR4c) have shorter, homologous cytoplasmic tails (Fig. 1B). Receptors composed of subunits with short cytoplasmic C-termini (GluR2/3) cycle continuously in and out of the synapse, with a time constant of about 15 min (Passafaro et al., 2001; Shi et al., 2001), whereas receptors containing long C-termini (GluR1/2 and GluR2/4) are added into synapses in an activity-dependent manner (Hayashi et al., 2000; Shi et al., 2001). Each subunit binds specific intracellular proteins through the C-terminal tail, and these interactions play important roles in controlling the trafficking of AMPARs and/or their stabilization at the synapses.

\section{AMPAR POST-TRANSLATIONAL MODIFICATIONS}

Phosphorylation is a key post-translational modification in regulating AMPAR function (Carvalho et al., 2000). It can 


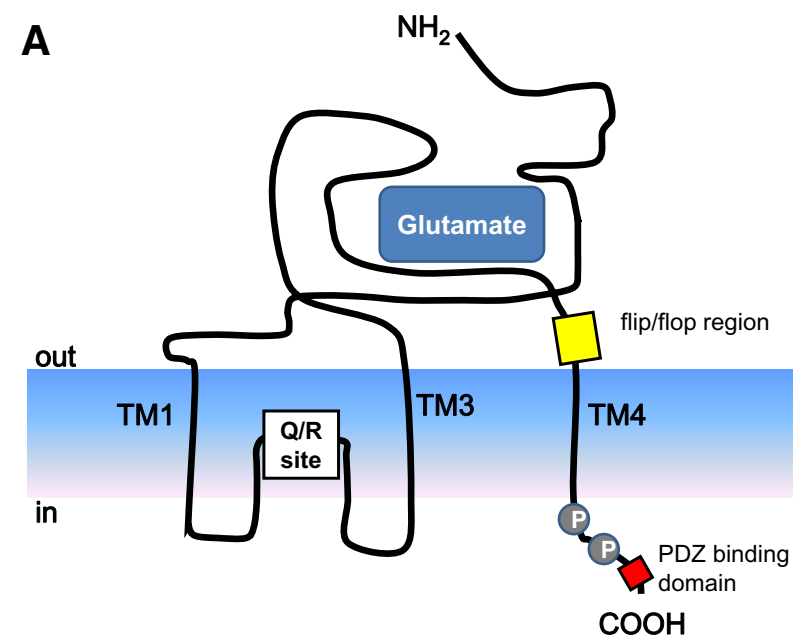

B

Long tail

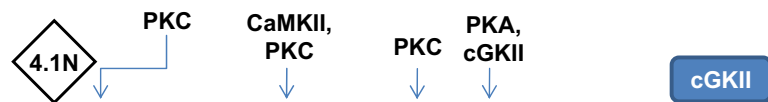

GIUR1 : EFCYKSRSESKRMKGFCLIPQQSINEAIRTSTLPRNSGAGASGGGGSGENGRVVSQDFPKSMQSIPCMSHSSGMP LGATGL

GluR2L : EFCYKSRAEAKRMKMTLSDVMRSKARLSITGSTGENGRVMTPEFPKAVHAVPYVSPGMGNVSVTDLS

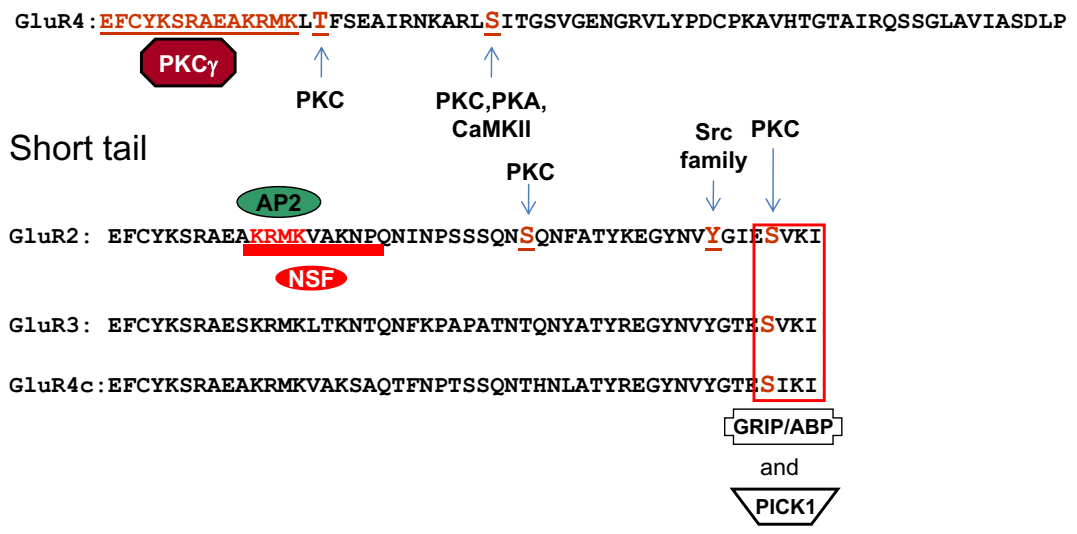

Fig. 1. Schematic representation of the topology of AMPA receptor subunits $(A)$. Sequence alignment of the intracellular C-terminal regions of the long-tailed (GluR1, GluR2L and GluR4) and short-tailed (GluR2, GluR3 and GluR4c) AMPA receptor subunits. The protein binding sites on AMPA receptor subunits (boxes) and the phosphorylation sites are underlined and indicated with a larger font size.

regulate the physiological properties of the channel as well as protein trafficking (Fig. 2). GluR1 subunit has been described to be phosphorylated at three serine residues located in the intracellular C-terminus: serine 831 (Ser831) can be phosphorylated by both protein kinase C (PKC) (Roche et al., 1996) and CaMKII (Mammen et al., 1997); serine 845 (Ser845) is a protein kinase A (PKA) and cGMP-dependent protein kinase II (cGKII) phosphorylation site (Roche et al., 1996; Serulle et al., 2007) and serine 818 (Ser818) is a substrate for PKC (Fig. 1B) (Boehm et al., 2006). LTP induction increases the CaMKII-dependent phosphorylation of GluR1 at Ser831 (Mammen et al., 1997). Although such phosphorylation may enhance the function of synaptic receptors (Benke et al., 1998), it does not seem to be required for receptor synaptic delivery, since mutations on GluR1-Ser831 that prevent its phosphorylation by CaMKII do not prevent delivery of the receptor to synapses by active CaMKII (Hayashi et al., 2000). Interestingly, mutations at Ser845, the PKA phosphorylation site of GluR1 (Roche et al., 1996), do prevent delivery of GluR1 to synapses by active CaMKII (Esteban et al., 2003a). On the other hand, PKA activity is necessary but not sufficient for the CaMKII-driven incorporation of GluR1 into synapses (Esteban et al., 2003a). It is important to note that both Ser831 and Ser845 are necessary, but not sufficient, to deliver AMPARs into synapses, which requires the activation of the CaMKII-Ras-MAPK (mitogen-activated protein kinase) pathway (Esteban, 2003b). 


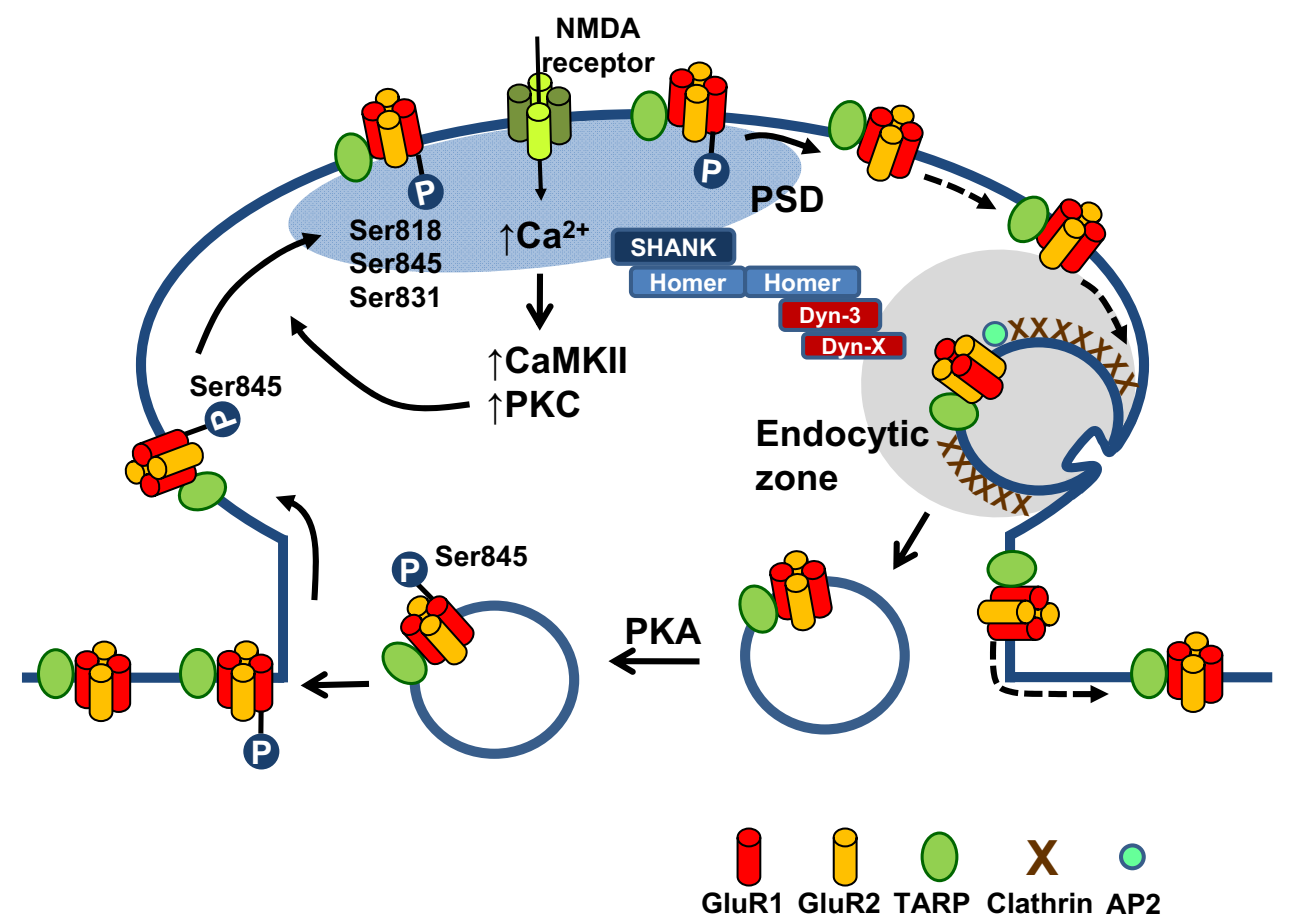

Fig. 2. Regulation of the intracellular traffic of GluR1-containing AMPA receptors. The intracellular pool of receptors is delivered to the synapse in an activity-dependent manner. The population of AMPA receptors present in the PSD has a limited mobility, in contrast with the non-synaptic receptors which diffuse in the membrane. The receptors internalized at the endocytic zone by a clathrin-mediated process may be then recycled. See text for further details.

Phosphorylation of GluR1 Ser818 by PKC is critical in LTP-driven incorporation of AMPARs into the postsynaptic membrane (see below) and is suggested to exert its function by facilitating the interaction between GluR1 and a delivery or tethering protein (Boehm et al., 2006).

In addition to the serine residues, recent work from Lee et al. (2007) reported threonine 840 (Thr840) as one of the major phosphorylation sites in GluR1. This site is phosphorylated by PKC in vitro and shows a high turnover rate under basal conditions in the hippocampus.

PKC also phosphorylates the GluR2 subunit. In this case, the phosphorylation occurs at the C-terminal sequence (IESVKI) within the PDZ (postsynaptic density 95/ disc large/zonula occludens-1) domain binding region through which GluR2 binds to different proteins (glutamate receptor interacting protein (GRIP)/ABP and protein interacting with C-kinase-1 (PICK1), see below), therefore modulating those interactions (Chung et al., 2000; Matsuda et al., 2000; Seidenman et al., 2003). Phosphorylation of GluR2 (Ser880) by PKC (Fig. 1B) decreases receptor binding to GRIP1, recruits PICK1 to excitatory synapses and facilitates rapid internalization of surface receptors (Chung et al., 2000). Chung et al. (2003) demonstrated that GluR2 phosphorylation at Ser880 is a critical event in the induction of cerebellar LTD (see below).

GluR2 is also phosphorylated at tyrosine 876 (Tyr876) in its C-terminus by the Src family protein tyrosine kinases, in vitro and in vivo (Fig. 1B) (Hayashi and Huganir, 2004). Interestingly, phosphorylation of this tyrosine residue has similar effects to the phosphorylation of Ser880. Phosphor- ylation of GluR2 on Tyr876 decreases the binding to GRIP1/ABP, but is without effect on the binding to PICK1, thus facilitating the AMPA- or NMDA-induced receptor internalization (Hayashi and Huganir, 2004).

GluR4 is expressed in the hippocampus during the early postnatal period, and spontaneous activity at this stage is sufficient to trigger GluR4 synaptic incorporation (Zhu et al., 2000). Phosphorylation of GluR4 at serine 842 (Ser842) by PKA (Fig. 1B) (Carvalho et al., 1999) is both necessary and sufficient for the delivery of GluR4-homomeric receptors to the synapse (Esteban et al., 2003a), and is regulated by metabotropic glutamate and dopamine receptors in retina cells (Gomes et al., 2004). In addition, PKC $\gamma$ interacts directly with GluR4 and phosphorylates Ser842 in vitro (Correia et al., 2003) and in cultured retina cells (Gomes et al., 2004). Disruption of this interaction prevents efficient receptor phosphorylation by PKC and the PKC-driven increase in cell surface expression of GluR4-containing AMPARs (Gomes et al., 2007a).

Protein palmitoylation is a reversible fatty acid acetylation that regulates protein trafficking and cellular localization. All AMPAR subunits can be palmitoylated on two cysteine residues in their membrane domain $\mathrm{M} 2$ and in their C-terminal region, in vitro and in vivo (Hayashi et al., 2005). Palmitoylation on M2 is upregulated by the palmitoyl-acyl transferase GODZ and leads to an accumulation of the receptor in the Golgi and a reduction of receptor surface expression. On the other hand, when palmitoylation occurs at the C-terminal domain it contributes to receptor internalization, by inhibiting receptor interaction 
with the 4.1N protein (Hayashi et al., 2005), which has previously been shown to stabilize AMPAR expression on the cell surface (Shen et al., 2000). Moreover, activation of GluRs by glutamate stimulation decreases receptor palmitoylation and recruits more AMPARs to the cell surface (Hayashi et al., 2005). Together these evidences suggest that palmitoylation may play important roles in the postsynaptic trafficking of AMPAR and in the regulation of excitatory synaptic transmission.

\section{AMPAR TRAFFIC}

\section{AMPAR biosynthesis and AMPAR interaction partners}

AMPAR subunits are synthesized and assembled in the rough endoplasmic reticulum (ER) and then inserted into the plasma membrane after crossing the Golgi apparatus. The assembly of AMPARs in the ER and subsequent ER exit is influenced by subunit-specific interactions and RNA editing of GluR2 at the Q/R site (Greger and Esteban, 2007). GluR2 is a critical subunit in determining mammalian AMPAR function. Most mature GluR2 protein contains an arginine residue $(R)$ within the re-entrant M2 membrane loop region at position 586 in place of the genomicallyencoded glutamine (Q) (Sommer et al., 1991). This Q/R editing (Fig. 1A) is specific to the GluR2 subunit and more than $95 \%$ of GluR2 mRNA transcripts are edited in the postnatal brain. The $Q / R$ site provides a key ER quality control checkpoint, since editing to Arg attenuates the formation of GluR2 homo-tetramers and establishes a stable GluR2 pool in the ER (Greger et al., 2002). This subunit appears to require assembly into heteromeric channels for ER export (Greger et al., 2003), and prolonged GluR2 ER residence may be a prerequisite for the formation of GluR2-containing heteromeric AMPARs later in development.

TARPs coassemble with AMPARs early in the synthetic pathway and control their maturation, trafficking, and biophysical properties (Nicoll et al., 2006; Ziff, 2007). Stargazin was originally identified as the mutant gene in the Stargazer mouse, which exhibits profound cerebellar ataxia and epilepsy (Osten and Stern-Bach, 2006), resulting from the lack of functional AMPAR channels in cerebellar granule cells (Chen et al., 2000; Schnell et al., 2002). This family of proteins comprises five isoforms: $\gamma-2$ (or Stargazin), $\gamma-3, \gamma-4, \gamma-7$, and $\gamma-8$, all of which share a weak homology to the $\gamma$ subunits of muscle voltage-dependent $\mathrm{Ca}^{2+}$ channels (VDCCs) (Burgess et al., 1999; Klugbauer et al., 2000). These proteins contain four TM domains and their carboxy terminus interact with the PDZ domains of postsynaptic density (PSD) 95 and with other membraneassociated guanylate kinase (MAGUK) family members (Chen et al., 2000).

Biochemical and cell biology studies have shown that TARPs are involved in folding and assembly of AMPAR, stabilizing and facilitating their export from the ER (Tomita et al., 2003; Vandenberghe et al., 2005). Furthermore, TARPs promote AMPARs surface expression (Chetkovich et al., 2002; Schnell et al., 2002; Tomita et al., 2003) and are critical for clustering AMPARs at excitatory synapses through their interaction with PSD-95 (Chen et al., 2000; Schnell et al., 2002), a major component of the postsynaptic scaffold (Kim and Sheng, 2004), and probably with other MAGUKs (Elias et al., 2006). Schnell et al. (2002) observed that PSD-95 overexpression in hippocampal slices enhances specifically synaptic AMPAR-mediated response without changing the number of surface AMPARs. Conversely, they describe that Stargazin overexpression increases selectively the number of extrasynaptic AMPARs without changing AMPAR-mediated synaptic currents. These observations indicate that the Stargazin/ PSD-95 interaction is involved in the stabilization of AMPARs at synapses.

In addition to the effect on AMPAR trafficking, Stargazin controls AMPAR channel gating by slowing glutamateinduced AMPAR deactivation and desensitization, and enhancing the channel conductance (Priel et al., 2005; Tomita et al., 2005; Nicoll et al., 2006). Moreover, in the presence of TARPs, the AMPARs competitive antagonist 6-cyano-7-nitroquinoxaline-2,3-dione (CNQX) acts as a partial agonist (Menuz et al., 2007). These results, together with the resolution of the crystal structure of CNQX bound to the TARP-less AMPAR LBD (Menuz et al., 2007), led the authors to propose a model where TARPs either strengthen the coupling between agonist-induced domain closure and channel opening, perhaps by promoting linker separation, or directly enhance the degree of domain closure induced by CNQX.

The final step of insertion of the receptors in the synaptic membrane involves tightly regulated events that depend on the subunit composition of the receptor and on specific signals contained within the C-termini. Several PDZ domain-containing proteins have been shown to participate in the process. The final four amino acids at the C-terminus of GluR1 form a group I PDZ ligand, while the tails of GluR2, GluR3 and GluR4c form group II PDZ ligands. GluR4 and GluR2L have distinct C-terminal tails and it is unclear whether they interact with classical PDZ domains. GluR1 was described to interact with SAP97 (Fig. 1B) (Leonard et al., 1998). The interaction between SAP97 and GluR1 first occurs in the receptor secretory pathway and is essential for the transport of the receptor from the ER to the cis face of the Golgi apparatus, with SAP97 dissociating from the complex at the plasma membrane (Sans et al., 2001). Also RIL [reversion-induced LIM gene (Schulz et al., 2004)] is an interactor for GluR1 and may be involved in actin-dependent trafficking of GluR1. Another actin adaptor, protein $4.1 \mathrm{~N}$, also associates with AMPARs and appears to stabilize the surface expression of GluR1 (Shen et al., 2000).

GRIP (Dong et al., 1997), AMPA receptor-binding protein (ABP), also known as GRIP2 (Srivastava et al., 1998), and PICK1 (Dev et al., 1999; Xia et al., 1999) can interact with the PDZ ligand at the extreme C-terminus of GluR2 and GluR3 (Fig. 1B) (Sheng and Sala, 2001). Mutations of the GluR2 PDZ binding site that selectively block GluR2 binding to ABP and GRIP accelerate GluR2 endocytosis at synapses (Osten et al., 2000). These findings identify ABP and GRIP as anchors that contribute to AMPAR synaptic 
abundance. Phosphorylation of GluR2 by PKC at Ser880 within the PDZ binding region prevents the association of GluR2 with ABP and GRIP, but not with PICK1 (Matsuda et al., 1999, 2000; Chung et al., 2000). PICK1 besides interacting with GluR2/3 C-terminus also interacts with $\mathrm{PKC} \alpha$, and it has been proposed that dimeric PICK1 can act to chaperone activated PKC and AMPARs (Chung et al., 2000; Perez et al., 2001). Several studies indicate that PICK1 regulates the surface expression of GluR2 (Perez et al., 2001; Terashima et al., 2004), and it has recently been shown, in a study using pHluorin-tagged GluR2 and fluorescence recovery after photobleaching (FRAP), that the phosphorylation state of GluR2 Ser880 residue, as well as binding of PICK1 to GluR2, regulates the rate of GluR2 recycling to the plasma membrane after NMDA receptor activation (Lin and Huganir, 2007).

GluR2 also binds NSF, an ATPase required for membrane fusion events (Rothman, 1994), which interacts with a membrane proximal segment of the C-terminus of GluR2 (Fig. 1B) (Nishimune et al., 1998; Osten et al., 1998; Song et al., 1998). This protein helps to maintain the synaptic expression of GluR2-containing AMPARs (Noel et al., 1999; Hanley et al., 2002). NSF displaces PICK1 from the PICK1-GluR2 complex and thereby facilitates the delivery or stabilization of GluR2 at the plasma membrane (Hanley et al., 2002).

Recent work demonstrates a role for AMPAR N-terminal protein-protein interactions either in receptor traffic or in synaptogenesis, which requires neurotransmitter receptors' recruitment to the development of postsynaptic specializations. Via its extracellular N-terminal domain, GluR2 promotes the formation and growth of dendritic spines in cultured hippocampal neurons (Passafaro et al., 2003), and overexpression of that domain increases the frequency of miniature excitatory postsynaptic currents (mEPSCs) (Saglietti et al., 2007). This mechanism has been described to involve a direct interaction of GluR2 $\mathrm{N}$-terminal domain with $\mathrm{N}$-cadherin, suggesting that GluR2 promotes spines and synapse formation by a structural interaction between its $\mathrm{N}$-terminal domain and the presynaptic terminal (Saglietti et al., 2007).

Members of the pentraxin family have been shown to cluster AMPARs (O'Brien et al., 1999; Sia et al., 2007). This family consists of neuronal-activity-regulated pentraxin (Narp) and neuronal pentraxin 1 (NP1), both secreted proteins homologous to the serum pentraxins (Schlimgen et al., 1995; Tsui et al., 1996), and neuronal pentraxin receptor (NPR), an integral membrane protein (Dodds et al., 1997). Narp and NP1 coimmunoprecipitate with AMPARs in heterologous cells (Xu et al., 2003), and Narp-expressing HEK cells seeded on neurons recruit GluR1 to sites where they contact neuronal dendrites (O'Brien et al., 1999). Recently, Sia et al. (2007) described that the presynaptically secreted NP1 and NPR bind to the GluR4 N-terminal domain and are critical trans-synaptic factors for GluR4 recruitment to synapses.

\section{AMPAR regulation by cell adhesion molecules (CAMs)}

Synaptic CAMs are known to play key roles in various aspects of dendritic spine structure and function, including early differentiation, maintenance, and plasticity. On the other hand, distribution of functional AMPARs is tightly correlated with spine geometry (Matsuzaki et al., 2001, 2004), and recent evidences suggest that CAMs can regulate AMPARs.

Integrins are TM heterodimers of $\alpha$ - and $\beta$-subunits (Giancotti and Ruoslahti, 1999; Coppolino and Dedhar, 2000; Schwartz and Shattil, 2000; van der Flier and Sonnenberg, 2001) and have been recently directly implicated in hippocampal LTP (Chan et al., 2006; Huang et al., 2006; Kramar et al., 2006). Infusion of an integrin ligand (the peptide GRGDSP) into rat hippocampal slices reversibly increased the slope and amplitude of excitatory postsynaptic potentials mediated by AMPARs (Kramar et al., 2003). In addition, it was shown that basal excitatory synaptic transmission through AMPARs (Chan et al., 2006) and LTP in the hippocampus are impaired in beta1-integrin knockout mice (Chan et al., 2006; Huang et al., 2006). These results suggest that synaptic integrins regulate glutamatergic transmission and this may occur through AMPARs.

Cadherins also play a role in AMPAR regulation. This family of proteins consist of homophilic adhesion molecules with five extracellular subdomains separated from the cytoplasmic domain by a single TM segment (Takeichi, 1990). Recently, several reports have shown that N-cadherin and its cognate cytoplasmic interacting protein betacatenin regulate synaptic structure and functions in an activity-dependent manner (Murase et al., 2002; Togashi et al., 2002; Yu and Malenka, 2003). This is of a particular interest because $\mathrm{N}$-cadherin has been shown to be modified by neuronal activity and to play important roles in synaptic plasticity (Tang et al., 1998; Bozdagi et al., 2000; Tanaka et al., 2000). N-cadherin associates and co-localizes with AMPARs in neurons, in a cis manner, and this association is regulated by the extracellular $\mathrm{Ca}^{2+}$ concentration (Nuriya and Huganir, 2006). AMPAR-N-cadherin interaction regulates AMPAR trafficking by increasing receptor surface expression both in heterologous cells and in neurons (Nuriya and Huganir, 2006). Another study demonstrated that cadherin can anchor AMPARs in complex with ABP/GRIP through a neural plakophilin-related arm protein (NPRAP; also called $\delta$-catenin) (Silverman et al., 2007), which binds to the juxtamembrane region of the cadherin intracellular domain. NPRAP also binds PSD-95, which is a scaffold for NMDA receptors, for AMPARs in complexes with the TARP auxiliary subunits, and for adhesion molecules. Together these data suggest that the association of $\mathrm{N}$-cadherin with AMPARs regulates AMPAR trafficking, and may provide a biochemical link between morphological plasticity and functional plasticity at dendritic spines.

Reelin is a large molecule of the extracellular matrix (ECM) which regulates neuronal positioning during the early stages of cortical development in vertebrate species. 
Reelin is also expressed in the adult brain, notably in the cerebral cortex, where it plays an important role in neuronal maturation, synaptic plasticity, and memory formation (Nimpf and Schneider, 2000; Weeber et al., 2002; Beffert et al., 2005; D'Arcangelo, 2005). Its action is mediated through the binding to two types of receptors: apoER2 (apolipoprotein E receptor 2) and VLDLR (very-low-density lipoprotein receptor). Qiu et al. (2006) found that reelin application to adult mice hippocampal slices leads to enhanced glutamatergic transmission mediated by NMDARs and AMPARs, through distinct mechanisms. They proposed that reelin signaling leads to activation of phosphatidylinositol 3-kinase (PI3-K) (Beffert et al., 2002), which drives the intracellular pool of AMPARs for synaptic delivery (Man et al., 2003), favoring synaptic transmission at resting membrane potentials.

A variety of proteins from the immunoglobulin-like family, such as Thy-1, NCAM, L1, contactin, telencephalin and neuroplastin-65 are associated with alterations in hippocampal synaptic plasticity, including LTP and LTD (Muller et al., 1996; Nosten-Bertrand et al., 1996; Bliss et al., 2000; Nakamura et al., 2001; Murai et al., 2002). Empson et al. (2006) showed that homophilic binding by neuroplastin-65 causes a sustained increase in phosphorylation of p38 MAPK, coincident with the p38 MAPK-sensitive loss of LTP and reduced surface expression of the GluR1 AMPAR subunit.

Polysialic acid (PSA) is a negatively charged carbohydrate that is predominantly carried by the neural cell adhesion molecule (NCAM) in mammals. NCAM and, in particular, PSA play important roles in cellular and synaptic plasticity. Making use of artificial lipid bilayers and of PSA from bacterial origin, Vaithianathan et al. (2004) recorded from single channels and demonstrate that colominic acid (polymer of $\mathrm{N}$-acetylneuraminic acid) can dramatically prolong AMPAR channel open time. In addition, colominic acid increased AMPARs currents in immature but not in mature CA1 pyramidal cells (Vaithianathan et al., 2004). These data reveal an age-dependent interaction between PSA and AMPARs that may modulate neuronal transmission and plasticity in the developing CNS.

\section{Vesicular traffic, synaptic targeting and lateral membrane diffusion of AMPARs}

Fast changes in the number of synaptic AMPARs occur during synaptic plasticity, and are probably accounted for by a combination of direct insertion/removal of AMPARs at synaptic and/or extrasynaptic sites and by their lateral diffusion to and from synapses, where they are stabilized by scaffold proteins in the PSD or by binding to extracellular ligands (Fig. 2). AMPARs are inserted at the cell surface through SNARE (soluble $\mathrm{N}$-ethylmaleimide-sensitive factor attachment protein receptors) -dependent exocytosis (Lledo et al., 1998; Luscher et al., 1999), and are removed by rapid ligand-induced endocytosis (Carroll et al., 1999; Man et al., 2000). Moreover, synaptic AMPARs are relatively immobile when compared with extrasynaptic AMPARs, as determined by optical monitoring of the surface trafficking of single receptors using quantum dots coupled to antibodies that recognize the extracellular region of AMPARs (Groc and Choquet, 2006). Local synaptic activity immobilizes GluR1-containing AMPARs at individual synapses (Ehlers et al., 2007).

The mechanisms regulating AMPAR exocytosis are subunit specific, since the exocytosis of the GluR2 subunit is rapid and constitutive, whereas GluR1 exocytosis is slow but inducible (Passafaro et al., 2001). In a recent study, real-time measurements of receptor exocytosis onto the surface of neurons have been performed in organotypic hippocampal slice cultures using time-lapse two-photon laser microscopy and AMPAR subunits tagged with superecliptic pHluorins (SEP), green-fluorescent protein (GFP) variants with strong $\mathrm{pH}$-dependent fluorescence (Kopec et al., 2006). Bath application of a solution that favors NMDAR activation, thereby strengthening glutamatergic synapses (see below), selectively increases GluR1-containing receptors on spine surfaces with no significant net change on the nearby dendrite (Kopec et al., 2006). Accordingly, Gerges et al. (2006) found that overexpression of a dominant negative form of an exocyst subunit (Exo70) impairs constitutive and regulated receptor insertion at the spine surface, and produces an accumulation of AMPARs intracellularly in spines, suggesting that exocytic vesicles containing AMPARs bud from intra-spine compartments into the synaptic surface. However, several studies suggest that exocytosis of AMPARs occurs predominantly at extrasynaptic sites. The real-time trafficking of native AMPARs was followed electrophysiologically, after silencing surface AMPARs using a photoreactive, irreversible antagonist of AMPARs (Adesnik et al., 2005). In this study, it was found that fast cycling of surface AMPARs with receptors from intracellular stores occurs exclusively at extrasynaptic somatic sites, and that the cycling of synaptic AMPARs occurs on a much longer timescale, suggesting that the newly inserted extrasynaptic AMPARs travel laterally along dendrites to synapses (Adesnik et al., 2005). Recently, visualization of discrete exocytic events mediating surface delivery of SEP-AMPARs in hippocampal slice cultures and in dissociated pyramidal neurons was reported (Yudowski et al., 2007). Yudowski and colleagues presented evidences suggesting that a major pathway for surface insertion of AMPARs is via exocytosis of AMPAR-carrying vesicles at extrasynaptic sites. These authors observed persistent exocytic events that dispersed slowly without producing a large increase in the surface receptor fluorescence at adjacent sites, and transient exocytic extrasynaptic events, which were capable of producing increased surface receptor fluorescence on nearby spines. This suggests that the transient exocytic events can drive surface delivery of AMPARs preferentially to nearby spines, eventually by long-range lateral diffusion.

The role of lateral diffusion in AMPAR trafficking has recently been investigated using novel methods that allow single receptor monitoring (Borgdorff and Choquet, 2002; Tardin et al., 2003; Groc et al., 2004; Bats et al., 2007; Ehlers et al., 2007), but also by FRAP (Ashby et al., 2006; Sharma et al., 2006; Bats et al., 2007). The initial studies used latex particles coated with an antibody against the 
extracellular domain of GluR2 (Borgdorff and Choquet, 2002) and were followed by single-molecule fluorescence imaging experiments [using organic dyes or semiconductor quantum dots; (Tardin et al., 2003; Groc et al., 2004; Bats et al., 2007; Ehlers et al., 2007)]. These experimental approaches showed that AMPARs diffuse rapidly in the extrasynaptic membrane, and a high proportion of mobile receptors are also detected inside synapses. Moreover, AMPARs enter and exit synapses through lateral diffusion, and this diffusion is regulated during protocols that modify receptor accumulation at synapses. Accordingly, FRAP studies in cultured hippocampal neurons showed that spine proteins, including EYFP-GluR1, undergo continual exchange with extrasynaptic pools (approximately $40 \%$ of total spine GluR1 exchanges with pools from the rest of the cell within $5 \mathrm{~min}$ ). Stimulation of synaptic NMDA receptors under conditions that raise the strength of glutamatergic synapses increased the mobile fraction of receptors but a slower kinetics for spine GluR1 was observed (Sharma et al., 2006). Other FRAP and fluorescence loss in photobleaching (FLIP) studies in cultured hippocampal neurons expressing SEP-GluR2 unraveled a population of surface receptors that continually move in and out of the dendritic spine by lateral diffusion, and showed a barrier to AMPAR lateral movement located at the spine neck (Ashby et al., 2006).

A recent attempt to understand the mechanisms that regulate the lateral diffusion of AMPAR led to evidence that the exchange of AMPAR by lateral diffusion from extrasynaptic to synaptic sites depends on the interaction of Stargazin with PSD-95, since disruption of this interaction increases AMPAR surface diffusion and prevents AMPAR accumulation at synapses (Bats et al., 2007). Interestingly, local synaptic activity reduces the diffusional exchange of GluR1 between synaptic and extrasynaptic domains, resulting in postsynaptic accumulation of GluR1-containing AMPAR. In contrast, at neighbor inactive synapses GluR1 was found to be highly mobile (Ehlers et al., 2007), in agreement with an earlier study showing that synapsespecific silencing of neurotransmission causes a reduction in synaptic GluR1-containing AMPARs, in comparison to nearby active synapses (Harms et al., 2005).

Regulated AMPAR internalization is mediated by clathrin-dependent endocytosis (Beattie et al., 2000; Man et al., 2000), and requires the interaction between GluR2 and AP2, a clathrin adaptor protein (Lee et al., 2002). In cultured neurons, several stimuli can cause AMPAR internalization, such as the activation of NMDARs (Carroll et al., 1999; Beattie et al., 2000; Ehlers, 2000), AMPARs (Lin et al., 2000), mGluRs (Snyder et al., 2001; Xiao et al., 2001) or insulin receptors (Lin et al., 2000; Man et al., 2000). Receptor internalization may be caused by different signaling pathways, and AMPARs are differentially sorted between recycling and degradative pathways following endocytosis, depending on the endocytic stimulus (Ehlers, 2000; Lin et al., 2000). AMPAR internalization triggered by NMDAR activation is $\mathrm{Ca}^{2+}$-dependent, requires protein phosphatase activity and dephosphorylation of GluR1, and is followed by rapid membrane reinsertion of AMPAR
(Ehlers, 2000). AMPA-induced AMPAR endocytosis depends on the secondary activation of voltage-gated calcium channels, and is triggered also by ligand binding independent of receptor activation (Lin et al., 2000). AMPARs internalized in response to AMPA stimulation also enter a recycling endosome system (Lin et al., 2000).

Several studies have revealed the presence of specializations dedicated to endocytosis stably positioned adjacent to the postsynaptic membrane in dendritic spines (Blanpied et al., 2002; Petralia et al., 2003; Racz et al., 2004). These endocytic zones lie in lateral domains of the spine, and they develop and persist independent of synaptic activity (Blanpied et al., 2002). Recently, Lu et al. (2007a) reported evidences that provide a mechanistic explanation for the retention of the endocytic zones close to the PSD. Correct positioning of the endocytic zones requires association between dynamin 3 , a postsynaptic GTPase with a role in severing the neck of invaginated clathrin-coated vesicles, and the postsynaptic adaptor Homer, which in turn binds to Shank. Synaptic localization of the endocytic zones was disrupted by overexpression of the proline-rich domain of dynamin 3, which inhibits the binding of wild-type dynamin 3 to Homer. Moreover, coupling of the endocytic zones to the postsynaptic densities requires oligomerization of dynamin 3 , and is disrupted by loss of endogenous dynamin 3. Surprisingly, the localization of the endocytic machinery close to the postsynaptic densities was found to play an important role in maintaining synaptic AMPARs and in sustaining basal excitatory transmission. To account for these counterintuitive evidences, it was suggested that endocytic zones at close proximity to the PSD may capture AMPARs laterally while they are diffusing out of the PSD, and promote their recycling back to the synapse. This model suggests that the endocytic zones adjacent to the PSD provide the means for maintaining synaptic AMPARs. It remains to be determined whether this mechanism is somehow specific to AMPARs, or whether the endocytic zones peripheral from the PSD play a general role in removing membrane proteins in the edge of the PSD.

Interestingly, Ashby et al. (2004) used pHluorin-GluR2 expressed in hippocampal neurons in culture to follow NMDAR-dependent AMPAR endocytosis, and found that in synaptic regions GluR2 fluorescence slowly declines after the period of NMDA application, whereas extrasynaptic pHluorin-GluR2 fluorescence decreased sharply during NMDA application, suggesting rapid internalization of extrasynaptic AMPARs. These results suggest that NMDA-receptor triggered synaptic removal of AMPARs is preceded by endocytosis of extrasynaptic AMPARs, which could promote lateral diffusion of synaptic AMPARs out of the PSD. It would be interesting to investigate what happens to the endocytic zones adjacent to the PSD under these experimental conditions.

The Arc/Arg3.1 immediate-early gene is regulated by neuronal activity. Arc/Arg3.1 mRNA is transported to dendrites, and accumulates at sites of synaptic activity, where it is translated (Guzowski et al., 2005), conferring temporal and spatial specificity to the expression of the Arc/Arg3.1 
protein. This protein interacts with dynamin 2 and with specific isoforms of endophilin, to localize to endosomes, and to enhance AMPAR endocytosis in hippocampal neurons (Chowdhury et al., 2006). In hippocampal neurons prepared from Arc/Arg3.1 knockout mice, receptor endocytosis is decreased, and the surface levels of AMPARs are upregulated, suggesting that the Arc/Arg3.1-regulated endocytic pathway modulates the basal level of AMPARs (Chowdhury et al., 2006). Another immediate-early gene, CPG2, a brain-specific splice variant of the syne-1 gene that encodes a protein specifically localized to the postsynaptic endocytotic zone of excitatory synapses, mediates both constitutive and regulated AMPAR endocytosis (Cottrell et al., 2004).

It is becoming more evident that exocytosis, lateral diffusion and endocytosis are key players in AMPAR trafficking. It still remains to be determined how these processes relate dynamically, to insert, retain and remove synaptic AMPARs. Further investigation in this field should reconcile the apparently contradictory evidences concerning the location and regulation of AMPAR surface delivery and removal.

\section{AMPAR PHOSPHORYLATION AND TRAFFICKING IN SYNAPTIC PLASTICITY}

AMPARs play a key role in the expression of LTP and LTD, which are extensively investigated forms of synaptic plasticity, thought to underlie learning and memory formation (Martin et al., 2000; Morris, 2006). LTP is characterized by a persistent increase in the efficacy of synaptic transmission, following a short period of high-frequency synaptic stimulation [e.g. (Morris, 2006)]. Pharmacological stimulation of excitatory synapses also induces a long-term increase in synaptic activity, named chemical LTP [e.g. (Broutman and Baudry, 2001; Lu et al., 2001; Park et al., 2004)]. In contrast, a period of low-frequency synaptic stimulation reduces synaptic strength (LTD). Increasing evidence suggests that at many excitatory synapses, phosphorylation of AMPARs, and their insertion or removal from the PSD, underlie the changes in synaptic strength associated with LTP or LTD, respectively.

\section{Role of AMPARs in LTP}

AMPARs present in the adult hippocampus contain GluR1 and GluR2, or GluR3 and GluR2 subunits (Wenthold et al., 1996). Several lines of evidence point to a central role of GluR1 in hippocampal LTP. Thus, GluR1 ${ }^{-1-}$ mice are deficient in LTP (Zamanillo et al., 1999), in contrast with the enhanced LTP observed in mice lacking GluR2 (Jia et al., 1996). Studies using hippocampal organotypic cultures transiently expressing GFP-tagged AMPAR subunits showed a rapid translocation of GluR1-GFP to dendritic spines following induction of LTP (Shi et al., 1999; Hayashi et al., 2000), which accounts, in part, for the increased response to synaptically released glutamate. The translocation of GluR1 to the membrane requires high-frequency stimulation of the synapse and is dependent on NMDA receptor activation (Shi et al., 1999). The same experimen- tal approach showed that GluR2 subunits are constitutively delivered to synapses, in contrast with GluR1. The GluR1 regulatory mechanism is dominant, since heteromeric receptors containing GluR1 and GluR2 subunits behave like the GluR1 (Shi et al., 2001). In vivo studies also showed a reversible increase in GluR1 and GluR2 protein levels in synaptoneurosomes (a subcellular fraction containing the pre and postsynaptic components of the synapse) isolated from the hippocampal CA1 region subjected to high-frequency stimulation (Lu et al., 2001). Similarly, LTP induction in the dentate gyrus of awake adult rats also induce a rapid NMDA receptor-dependent increase in the surface expression of GluR1-GluR3 subunits, but GluR1 was the only AMPAR subunit with an increased expression in the post-synaptic density (Williams et al., 2007). Recent studies showed that LTP induces a rapid but transient increase in synaptic expression of GluR2-lacking $\mathrm{Ca}^{2+}$-permeable AMPARs in 10 to 12-day-old mice. Although these receptors are subsequently replaced by GluR2-containing AMPARs, their transient expression in the synapse increases $\mathrm{Ca}^{2+}$ permeability, and may contribute to the stabilization of LTP (Plant et al., 2006; Lu et al., 2007b). At later developmental stages GluR2-lacking AMPARs are no longer required for the early phase of LTP (Lu et al., 2007b), which may explain the discrepancies found in the literature concerning this issue (Adesnik and Nicoll, 2007; Gray et al., 2007).

Under resting conditions AMPARs are recycled in a constitutive manner between synapses and intracellular membrane compartments, where they are sorted for degradation or for reinsertion at synapses (Ehlers, 2000; Passafaro et al., 2001) (see above). The transport of GluR1containing AMPARs to the plasma membrane from recycling endosomes is enhanced in response to LTP-inducing stimuli, thereby increasing synaptic efficacy (Broutman and Baudry, 2001; Park et al., 2004). The recycling pool of AMPARs has been shown to supply not only AMPARs but also lipid membrane for extension of dendritic spines during LTP (Park et al., 2004, 2006). The delivery of AMPARs to the synapse requires membrane fusion events, since inactivation of postsynaptic SNAREs with botulinum toxin reduces LTP induced by tetanic stimulation in the CA1 region of the hippocampus (Lledo et al., 1998). Similar studies where LTP was induced in cultured hippocampal neurons by stimulation of postsynaptic NMDA receptors with glycine also showed a tetanus toxin-sensitive (SNARE dependent) AMPAR insertion into synapses during LTP (Lu et al., 2001). A brief stimulation of $D_{1}$ dopamine receptors, which facilitates LTP in neurons of the prefrontal cortex, also led to the clustering of GluR1-containing AMPARs near but not within the PSD. In this model, activation of NMDA receptors is required to induce the synaptic localization of AMPARs (Sun et al., 2005). The Cterminal PDZ ligand of the GluR1 subunit plays a key role in the activity-dependent trafficking of AMPARs to spines (Piccini and Malinow, 2002) and synapses (Hayashi et al., 2000; Kim et al., 2001). A model was proposed according to which LTP activates CaMKII, which then phosphorylates GluR1 and a protein that binds to the PDZ domain of 
GluR1 (Hayashi et al., 2000; Shi et al., 2001). However, the role of the PDZ binding domain in the trafficking of GluR1 is still controversial (Kim et al., 2005). A recent study showed the delivery of a recombinant cytosolic GluR1 C-terminal fragment to the PSD after induction of LTP, and synaptic incorporation of this construct was sufficient to allow spine enlargement (Kopec et al., 2007). Therefore, in addition to the functional role of GluR1 delivery to the synapse, to increase synaptic strength, it also plays a structural role, increasing spine size.

PSD-95 may also function in the anchoring of GluR1 containing AMPARs, since expression of this protein in hippocampal slice cultures upregulates the amount of GluR1 found in synapses and increases synaptic transmission, occluding LTP (Ehrlich and Malinow, 2004; Gerges et al., 2004). An enhancement of LTP is also observed in PSD-95 knockout mice (Migaud et al., 1998), and similar findings were reported in another deletion mutant of PSD-95 (Beique et al., 2006). This suggests that the activity-dependent delivery of AMPARs to the synapse during LTP may occur in the absence of PSD-95, and may be mediated, for example, by Stargazin, which binds both AMPARs and PSD-95 (Schnell et al., 2002).

Phosphorylation of both GluR1-Ser831 (Barria et al., 1997; Lee et al., 2000., 2003) and GluR1-Ser845 (Lee et al., 2000; Esteban et al., 2003a) were originally suggested to mediate LTP expression. The use of phosphospecific antibodies, which bind GluR1 only when phosphorylated on Ser831 or on Ser845, showed that both sites are phosphorylated upon induction of LTP in the CA1 region of the hippocampus (Lee et al., 2000). Interestingly, the specific phosphorylation site involved in the expression of LTP depends on the history of the synapse, since high-frequency stimulation of naive synapses or of previously depressed synapses increases the phosphorylation of Ser831 (CaMKII phosphorylation site) and Ser845 (PKA phosphorylation site), respectively (Lee et al., 2000). The studies using adult mice with knock-in mutations in the Ser831 and Ser845 GluR1 phosphorylation sites showed a substantial reduction in the expression of LTP in the hippocampal CA1 region, correlated with an impairment in the retention of rapidly acquired new learning, but LTP was not completely absent when compared with the wild-type animals (Lee et al., 2003). GluR1 phosphorylation at Ser831 is also observed in the hippocampus of rats subjected to contextual fear conditioning (Shukla et al., 2007). Recent studies showed that PKC also phosphorylates GluR1 at Ser818 (Boehm et al., 2006) and at Thr840 (Lee et al., 2007), being the former site crucial for LTP.

The mechanisms whereby phosphorylation of GluR1 contributes to LTP are still not fully elucidated. Postsynaptic expression of a constitutively active form of CaMKII in hippocampal slices enhances synaptic transmission and prevents further induction of LTP, suggesting that CaMKII and LTP upregulate synaptic transmission through the same mechanism (Pettit et al., 1994; Lledo et al., 1998). The effect of constitutively active CaMKII on synaptic delivery of GluR1 is abrogated by inhibition of PKA, but activation of PKA signaling independently is not enough to induce delivery of the receptors to the synapse (Esteban et al., 2003a). Also, activation of PKA signaling with forskolin and rolipram increases the amount of GluR1 associated with the plasma membrane in cultured hippocampal neurons, but no major changes in synaptic activity are observed under these conditions (Oh et al., 2006), suggesting that there is no delivery of AMPARs to the synapse. However, when PKA activity is associated with stimulation of synaptic NMDA receptors there is an increased incorporation of AMPARs into synapses, and induction of LTP (Oh et al., 2006). Taken together, these evidences suggest that GluR1 phosphorylation of Ser845 delivers AMPARs to the plasma membrane, being the influx of $\mathrm{Ca}^{2+}$ through NMDA receptors necessary for the diffusion of the receptors until they reach the synapse, promoting synaptic potentiation (Oh et al., 2006). A recent study showed that GluR1 phosphorylation at Ser845 may also be accomplished by cGKII, which complements the PKA-induced surface increase of GluR1 (Serulle et al., 2007). The delivery of GluR1-containing AMPARs to the synapse and/or their stabilization in the synaptic compartment may also depend on the phosphorylation at Ser818 by PKC (Boehm et al., 2006) and on the CaMKII-dependent phosphorylation of a PDZ domain containing substrate that remains to be identified (Hayashi et al., 2000).

In addition to the effects on receptor trafficking, phosphorylation of GluR1 may also regulate its electrophysiological properties, contributing to synaptic potentiation. Thus, phosphorylation of GluR1 on Ser831 and Ser845 increases the apparent single-channel conductance (Derkach et al., 1999) and the apparent open-channel probability (Banke et al., 2000), respectively. However, under normal conditions GluR1 phosphorylation on Ser831 may not affect its electrophysiological properties, since a recent study showed no phosphorylation-induced increase in single AMPA channel properties when GluR1 is oligomerized with GluR2 (Oh and Derkach, 2005), which is the case in most native AMPARs (Wenthold et al., 1996).

The small GTPase Ras mediates the NMDA receptor and CaMKII signaling that drives synaptic accumulation of AMPAR subunits with long cytoplasmic tails during LTP (Zhu et al., 2002). Under resting conditions, the spontaneous neuronal activity contributes to low levels of Ras activity which are still sufficient to activate the Ras/ERK (extracellular signal-regulated kinase) signaling pathway, driving GluR2L to the synapse. An increase in neuronal activity further upregulates Ras, allowing the activation of the Ras-PI3-K signaling pathway, which drives GluR1 to synapses (Qin et al., 2005). It was suggested that the Ras/ERK and Ras-PI3-K pathways lead to synaptic delivery of GluR1 subunits by triggering the phosphorylation of Ser845 and Ser831 of GluR1, respectively, and the delivery of GluR2L is dependent on Ser842 phosphorylation induced by the former signaling pathway. A similar mechanism may be involved in the synaptic delivery of GluR1 subunits in hippocampal neurons exposed to BDNF (Caldeira et al., 2007), a neurotrophin that activates the Ras/ ERK and the PI3-K signaling pathways in cultured hippocampal neurons (Almeida et al., 2005). Activation of the 
Trk neurotrophin receptors by BDNF induces GluR1 phosphorylation on Ser831 (Caldeira et al., 2007), and plays a key role in LTP in the hippocampus [reviewed in (Carvalho et al., 2008)]. However, since it is very unlikely that ERK and PKB/Akt directly phosphorylate GluR1 or GluR2L, it remains to be determined which are the downstream signaling mechanisms involved. Also, the mechanisms involved in the regulation of Ras activity that are relevant to its effects in the regulation of AMPAR trafficking remain unknown. Rab8 is a distinct small GTPase that is also necessary for the synaptic delivery of GluR1-containing AMPARs induced by a constitutively active form of CaMKII, overexpression of PSD-95 and induction of LTP in cultured hippocampal slices (Gerges et al., 2004). Rab8 is present in both trans-Golgi network and recycling endosomes (Ang et al., 2003), but it was proposed that the effects of this small GTPase on LTP occur at the level of the former compartment (Gerges et al., 2004).

Several proteins of the PSD that interact with AMPARs have been shown to play a role in synaptic plasticity, by modulating the trafficking of the receptors. Overexpression of some of the proteins of the TARPs family leads to the accumulation of AMPARs in non-synaptic regions (Schnell et al., 2002; Rouach et al., 2005), in agreement with the two-step model for AMPAR trafficking in LTP. One of the TARPs, Stargazin $(\gamma-2)$, is phosphorylated at the C-terminal region by CaMKII and PKC, and the phosphorylated protein enhances AMPAR activity. Phosphorylation of Stargazin is dynamically regulated by NMDA receptor activation, and inhibition of Stargazin phosphorylation disrupts the dynamic recruitment of AMPARs necessary for LTP (Tomita et al., 2005). The synaptic delivery of AMPARs induced by Stargazin phosphorylation also requires the Stargazin PSD-95 PDZ binding site (Tomita et al., 2005), but how phosphorylation of this TARP promotes synaptic trafficking is still unknown.

The presence of the molecular machinery necessary for translation activity in spines and dendritic shafts (Steward and Levy, 1982; Tang and Schuman, 2002; Asaki et al., 2003), and the observed translocation of polyribosomes from dendritic shafts to spines following tetanic stimulation, which also increases the number of spines that contain polyribosomes (Ostroff et al., 2002), suggest that local protein synthesis may play an important role in synaptic plasticity. Accordingly, an overall increase in protein synthesis was observed in experiments where patterned synaptic stimulation was paired with muscarinic receptor activation with carbachol, in hippocampal slices (Feig and Lipton, 1993). The mRNAs coding for AMPAR subunits are found in dendrites, suggesting that local synthesis of AMPAR subunits may determine the abundance of receptors and/or their composition (Kacharmina et al., 2000; Ju et al., 2004; Grooms et al., 2006). An elegant study using the arsenic-based dyes FIAsH and ReAsH showed that transfected tagged GluR1 and GluR2 subunits can be synthesized in a dendritic compartment independent from the cell body, in cultured hippocampal neurons (Ju et al., 2004). Studies using a protein synthesis reporter consisting of GFP flanked by the $5^{\prime}$ and $3^{\prime}$ untranslated regions from the CaMKII $\alpha$-subunit, which contains information sufficient for the dendritic localization of the mRNA, also showed that BDNF may induce dendritic protein synthesis (Aakalu et al., 2001). The neurotrophin BDNF plays an important role in synaptic plasticity (Carvalho et al., 2008), and studies in hyppocampal synaptoneurosomes showed that BDNF induces local synthesis of GluR1 (Schratt et al., 2004). Activation of $D_{1}$-type dopamine receptors also increases rapidly GluR1 protein synthesis and enhances the frequency of spontaneous mEPSCs in hippocampal neurons (Smith et al., 2005). However, it remains to be determined to what extent the local synthesis of AMPAR subunits contributes to LTP.

\section{Role of AMPARs in LTD}

Low levels of synaptic stimulation can activate NMDARs to produce NMDAR-dependent LTD of glutamatergic synaptic transmission, or activate mGluRs, to produce mGluRdependent LTD. The two forms of LTD are thought to result from internalization of surface AMPARs in both hippocampal pyramidal neurons and cerebellar Purkinje cells.

Hippocampal LTD. In the CA1 region of the hippocampus, two mechanistically distinct forms of LTD can be induced, by triggering the activation of NMDARs or of mGluRs (Oliet et al., 1997). Interestingly, the magnitude of NMDAR-dependent LTD in the CA1 area of the hippocampus correlates with cognitive performance in young rats, whereas the magnitude of NMDAR-independent LTD correlates favorably with cognitive outcome in aged rats (Lee et al., 2005).

NMDAR-dependent LTD in the CA1 region of the hippocampus is known to require a moderate increase in postsynaptic calcium (Cummings et al., 1996), activation of protein phosphatases (Mulkey et al., 1993, 1994), dephosphorylation of the GluR1 subunit of AMPARs (Lee et al., 2000, 2003), and AMPAR internalization (Beattie et al., 2000; Carroll et al., 2001). Regulated endocytosis of AMPARs requires the interaction between GluR2 and the clathrin adaptor protein AP2 (Lee et al., 2002). The neuronal calcium sensor hippocalcin binds the $\beta 2$-adaptin subunit of the AP2 adaptor, in a calcium-sensitive manner, and infusion of a truncated mutant of hippocalcin, that lacks the calcium binding domains, prevents synaptically evoked LTD (Palmer et al., 2005a). These evidences suggest that the AP2-hippocalcin complex may act as a calcium sensor that couples NMDAR activation to regulated endocytosis of AMPARs during LTD. Additionally, a recent study shows that bath application of NMDA for a short period to hippocampal neurons in culture, a protocol used to induce chemical LTD, causes a dramatic decrease in the phosphorylation of PSD-95 on Ser295, and overexpression of the phosphomimicking Ser295Asp mutant of PSD95 blocks AMPAR internalization and LTD (Kim et al., 2007).

There are evidences leading to conflicting models regarding the role of GluR2 phosphorylation at Ser880, and GluR2 interaction with PICK1 and GRIP/ABP, in hippocampal LTD. Perez et al. (2001) found evidences that, similar to what has been found concerning cerebellar LTD 
(see below), disruption of the GluR2-GRIP1/ABP interaction by GluR2 phosphorylation results in the removal of synaptic receptors, by facilitation of the GluR2-PICK1 interactions. This model is further supported by a study in hippocampal slice cultures, where mimicking GluR2 Ser880 phosphorylation was found to exclude receptors from synapses, to depress transmission and to partially occlude LTD (Seidenman et al., 2003), and by a study showing that a Bin/amphyphysin/Rvs (BAR) domain mutant of PICK, unable to bind lipids, impairs expression of LTD in hippocampal neurons (Jin et al., 2006). On the other hand, Daw et al. (2000) reported that Ser880 phosphorylation can reverse LTD, by disrupting the intracellular retention of GluR2 by GRIP/ABP, and allowing receptors to be delivered to the synapse. The recent study by Lin and Huganir (2007) indicates that the binding of PICK1 to GluR2 regulates intracellular pools of GluR2 in recycling endosomes, that may be regulated differentially in response to different signaling pathways.

NMDAR-dependent LTD induction produces a rapid and transient increase of the active, GTP-bound, small GTPase Rab5, which drives the specific internalization of synaptic AMPARs in a clathrin-dependent manner, and is required for hippocampal LTD (Brown et al., 2005). In addition, there are evidences that the Rap1-p38 MAPK pathway is also involved in the NMDAR-dependent LTD in CA1 synapses (Zhu et al., 2002).

Arc/Arg3.1 is an immediate early gene which expression is increased by neuronal activity, and which is specifically targeted to stimulated synaptic areas. Arc has recently been found to reduce AMPAR-mediated currents, by endocytic removal of AMPAR composed of GluR2/ GluR3, and Arc overexpression occludes NMDAR-dependent hippocampal LTD (Rial Verde et al., 2006). Accordingly, hippocampal LTD is significantly impaired in $\mathrm{Arcl}$ Arg3.1 knockout mice, and these mice fail to form longlasting memories (Plath et al., 2006).

mGluR-mediated LTD at CA1 synapses in the hippocampus can be induced by agonists selective for group I mGluRs (Palmer et al., 1997), relies on dendritic protein synthesis (Huber et al., 2000), and involves activation of MAPKs (Gallagher et al., 2004; Huang et al., 2004) and protein tyrosine phosphatases (Moult et al., 2002). mGluRinduced LTD is associated with a decrease of surface GluR1 AMPAR clusters (Snyder et al., 2001), and with tyrosine dephosphorylation of GluR2 AMPAR subunit (Moult et al., 2006).

Interestingly, beta-amyloid $(\mathrm{A} \beta)$, the peptide generated from the amyloid precursor protein and which is believed to underlie the pathophysiology of Alzheimer's disease, drives the loss of cell surface AMPARs from CA1 hippocampal pyramidal neurons, employing signaling pathways of LTD (Hsieh et al., 2006). In fact, $A \beta$-induced synaptic depression partially mimics and occludes mGluRdependent LTD, and AMPAR endocytosis is required for $\mathrm{A} \beta$-induced synaptic depression.

Cerebellar LTD. Cerebellar LTD corresponds to a persistent decrease in synaptic strength at the parallel
fiber-Purkinje cell synapses, which is thought to be critical for some types of motor learning, and which is induced by coincident repeated activation of parallel fiber and climbing fiber inputs to Purkinje cells (Ito, 2001, 2002). The simultaneous activation of AMPARs, mGluRs and voltage-gated calcium channels on postsynaptic Purkinje cells induces cerebellar LTD (Ito, 2001, 2002), by raising the postsynaptic calcium concentration and activating PKC.

Expression of cerebellar LTD requires clathrin-mediated endocytosis (Wang and Linden, 2000), presumably of AMPARs, following GluR2 phosphorylation at Ser880 by PKC (Chung et al., 2003). In fact, LTD was absent in cultured cerebellar Purkinje cells from mutant mice lacking GluR2 and could be rescued by transient transfection with the wild-type GluR2 subunit. Transfection with a point mutant that eliminated PKC phosphorylation of Ser880 in the carboxy-terminal PDZ ligand of GluR2 failed to restore LTD. In contrast, transfection with a point mutant that mimicked phosphorylation at Ser880 occluded subsequent LTD (Chung et al., 2003). PKC phosphorylation of the AMPAR GluR2 subunit differentially modulates its interaction with the PDZ domain-containing proteins GRIP1 and PICK1. Phosphorylation of Ser880 in the GluR2 PDZ ligand decreases GluR2 binding to GRIP1 but not to PICK1 (Matsuda et al., 1999; Chung et al., 2000). By disrupting the interaction of GluR2 with GRIP1, Ser880 phosphorylation by PKC promotes GluR2 binding to PICK1, and PICK1-mediated internalization of AMPARs during LTP (Chung et al., 2000; Perez et al., 2001; Chung et al., 2003). $A$ recent study shows that targeted in vivo mutation of PICK1 eliminates cerebellar LTD, which can be rescued in cerebellar cultures from mice lacking PICK1 by transfection of wild-type PICK1, but not of a PDZ mutant of PICK1 or of a mutant lacking the lipid-binding BAR domain (Steinberg et al., 2006), a protein module of about 200 amino acids, frequently found in proteins involved in membrane trafficking. PICK1 has also been shown to bind calcium ions, and the PICK1-GluR2 interaction in neurons is calcium-sensitive, with weak binding at zero calcium, stronger binding at $\sim 15 \mu \mathrm{M}$ of intracellular calcium, and low binging at higher calcium concentrations (Hanley and Henley, 2005). This would allow PICK1 to respond to a local lowmicromolar concentration of calcium, to bind GluR2 and initiate AMPAR endocytosis. In the presence of a large calcium signal, the affinity of PICK1 for GluR2 would be decreased. PICK1 may thus play a role in distinguishing between the calcium signals involved in LTP and LTD.

LTD of the parallel fiber (PF) -Purkinje cell synapses also requires the participation of $\delta 2$ glutamate receptors (GluR $\delta 2$ ), which are predominantly expressed postsynaptically (Landsend et al., 1997). This form of plasticity is thought to underlie motor coordination and information storage (Ito, 1989; Hansel et al., 2001; Ito, 2001), but the molecular mechanisms involved are still not fully understood. This is in part due to limited current understanding about the signaling activity of these receptors. Although GluR $\delta 2$ has been considered as a subunit of ionotropic glutamate receptors, they were never shown to bind glutamate, or to be incorporated into native ionotropic gluta- 
mate receptors [reviewed in (Yuzaki, 2003)]. Furthermore, GluR $\delta 2$ do not contribute to normal excitatory postsynaptic currents (Kano and Kato, 1987) and a recent study suggested a non-ionotropic receptor function of GluR $\delta 2$ in the control of cerebellar synaptic plasticity (Kakegawa et al., 2007). Several lines of evidence suggest that these subunits play an important role in parallel fiber-Purkinje cell LTD. The induction of LTD is abrogated when the expression of GluR $\delta 2$ is knocked down using antisense oligonulceotides (Hirano et al., 1994; Jeromin et al., 1996) or in knockout mice (Hirano et al., 1995; Kashiwabuchi et al., 1995), and exogenous expression of the receptors in knockout Purkinje neurons or knockout mice rescues LTD induction (Hirai et al., 2005; Hirano, 2006). An antibody against the LAOBP (lysine-arginine-ornitine-binding protein) -like extracellular domain of GluR $\delta 2$ induces an LTDlike response in cultured Purkinje neurons, and the same experimental strategy leads to internalization of AMPARs, reduces parallel fiber-Purkinje cell synaptic transmission and abolishes LTD (Hirai et al., 2003). The analysis of the PDZ proteins that interact with GluR82, including nPIST (Yue et al., 2002), PSD-93 (Roche et al., 1999), PTPMEH (Hironaka et al., 2000), shank (Uemura et al., 2004), delphilin (Miyagi et al., 2002) and SCAM/MAGI-2 (Yap et al., 2003a), and other interactors lacking PDZ domains, including spectrin (Hirai and Matsuda, 1999), AP4 (Yap et al., 2003b) and the microtubule-associated protein EMAP (Ly et al., 2002), may provide clues about the regulation of the trafficking and function of this receptor. Interestingly, a recent study showed an attenuation of LTD at the parallel fiber-Purkinje cell synapses in PTPMEH-knockout mice (Kina et al., 2007).

\section{AMPARS IN HOMEOSTATIC PLASTICITY}

Homeostatic synaptic scaling complements the Hebbian forms of plasticity (LTP and LTD), stabilizing the activity of a neuron by scaling up or down the strength of all synapses, proportionally to their initial strength (Turrigiano, 2007). Without any stabilizing mechanisms, LTP and LTD would lead neuronal activity to excessive excitation or to quiescence, respectively. Synaptic scaling provides the negative feedback to maintain neuronal activity within a functional range.

This form of plasticity acts through synergistic presynaptic and postsynaptic changes (Turrigiano, 2007). We will review here how changes in postsynaptic AMPAR accumulation contribute to synaptic scaling of excitatory synapses. Chronic manipulations of neuronal activity in dissociated cultured neurons produce effects on the number of synaptic AMPARs, and on AMPAR-mediated excitatory postsynaptic currents (Lissin et al., 1998; O'Brien et al., 1998; Turrigiano et al., 1998). Increasing activity by chronically blocking inhibitory synaptic transmissision using picrotoxin leads to a decrease in the number of surface AMPARs in hippocampal (Lissin et al., 1998), spinal (O'Brien et al., 1998) or cortical (Turrigiano et al., 1998) neurons in culture. On the other hand, chronic application of the glutamate receptor antagonists $\mathrm{CNQX}$ and $\mathrm{APV}$ to cultured spinal cord neurons caused an increase in the surface expression of AMPARs at synapses, and in the amplitude of AMPAR-mediated mEPSCs (O'Brien et al., 1998), and chronic blockade of AMPARs in cultured hippocampal neurons increased the number, size and fluorescent intensity of AMPAR clusters and rapidly induced the appearance of AMPARs at silent synapses (Liao et al., 1999).

Several activity-dependent molecular signals have been implicated in the molecular mechanisms underlying synaptic scaling. Secreted factors such as BDNF and the proinflammatory cytokine tumor necrosis factor- $\alpha$ (TNF $\alpha$ ), as well as the immediate early gene product Arc, have been proposed to play a role in synaptic scaling (Turrigiano, 2007). Chronic BDNF treatment of cortical cultures can overcome the effect of chronic synaptic activity blockade (Rutherford et al., 1998), and TNF $\alpha$, secreted from glia cells, appears to be necessary for the increase in the level of synaptic AMPARs caused by long periods of activity blockade using TTX, a voltage-gated sodium channel blocker (Stellwagen and Malenka, 2006). The fact that a factor released by glia cells is required for synaptic scaling indicates that network, rather than cell-autonomous, changes in activity are implicated in the form of synaptic scaling mediated by TNF $\alpha$. The expression of the immediate early gene Arc is regulated by the chronic manipulations of activity in culture which are used to induce synaptic scaling, with high activity inducing high levels of Arc protein and activity blockade decreasing Arc protein levels. Moreover, overexpression of Arc blocks the homeostatic increases in AMPAR function induced by chronic activity blockade in culture (Shepherd et al., 2006), in agreement with the role of Arc in AMPAR endocytosis (Chowdhury et al., 2006), and hippocampal neurons from Arc KO mice show no synaptic scaling (Shepherd et al., 2006). The relative role of BDNF, TNF $\alpha$ and Arc in signaling changes in activity to induce or modulate synaptic scaling is still unclear.

Importantly, synaptic scaling was observed in vivo in cortical synapses following sensory deprivation (Desai et al., 2002; Goel et al., 2006). In the visual cortex, 1 week of dark rearing resulted in an increase in the ration of GluR1 to GluR2 in the postsynaptic densities. Conversly, in the somatosensory cortex, dark rearing decreased the GluR1/ GluR2 ratio (Goel et al., 2006). These evidences suggest that manipulation of visual experience regulates not only synaptic AMPARs in the visual cortex, but also results in complementary changes in the somatosensory cortex, and indicate that the regulation of AMPARs is a downstream mechanism for homeostatic plasticity in vivo.

\section{CONCLUSION}

The recent advances in the study of the molecular mechanisms of regulation of AMPARs have contributed, to a great extent, to the understanding of synaptic plasticity. Future studies concerning the signaling mechanisms governing AMPAR trafficking, the direct/indirect interaction of AMPAR subunits with intracellular proteins, and the spatial 
distribution of the receptor trafficking will contribute to a better understanding of LTP and LTD. In particular, the recent development of molecular imaging tools may allow determining how receptor exocytosis, lateral diffusion and endocytosis relate dynamically, to insert, retain and remove synaptic AMPARs during synaptic plasticity. Furthermore, the presence of the molecular machinery required for the synthesis of AMPAR subunits in dendrites suggests that local translation may play a regulatory role of AMPAR properties and trafficking.

Acknowledgments-The work in the authors' laboratories is funded by Fundação para a Ciência e a Tecnologia and FEDER, Portugal (POCTI/BCI/46466/2002; POCI/SAU-NEU/58955/2004; PTDCISAU-FCF/72283/2006).

\section{REFERENCES}

Aakalu G, Smith WB, Nguyen N, Jiang C, Schuman EM (2001) Dynamic visualization of local protein synthesis in hippocampal neurons. Neuron 30:489-502.

Adesnik H, Nicoll RA (2007) Conservation of glutamate receptor 2-containing AMPA receptors during long-term potentiation. J Neurosci 27:4598-4602.

Adesnik H, Nicoll RA, England PM (2005) Photoinactivation of native AMPA receptors reveals their real-time trafficking. Neuron 48: 977-985.

Almeida RD, Manadas BJ, Melo CV, Gomes JR, Mendes CS, Graos MM, Carvalho RF, Carvalho AP, Duarte CB (2005) Neuroprotection by BDNF against glutamate-induced apoptotic cell death is mediated by ERK and PI3-kinase pathways. Cell Death Differ 12:1329-1343.

Ang AL, Folsch H, Koivisto UM, Pypaert M, Mellman I (2003) The Rab8 GTPase selectively regulates AP-1B-dependent basolateral transport in polarized Madin-Darby canine kidney cells. J Cell Biol 163:339-350.

Asaki C, Usuda N, Nakazawa A, Kametani K, Suzuki T (2003) Localization of translational components at the ultramicroscopic level at postsynaptic sites of the rat brain. Brain Res 972:168-176.

Ashby MC, De La Rue SA, Ralph GS, Uney J, Collingridge GL, Henley JM (2004) Removal of AMPA receptors (AMPARs) from synapses is preceded by transient endocytosis of extrasynaptic AMPARs. $\mathrm{J}$ Neurosci 24:5172-5176.

Ashby MC, Maier SR, Nishimune A, Henley JM (2006) Lateral diffusion drives constitutive exchange of AMPA receptors at dendritic spines and is regulated by spine morphology. J Neurosci 26:7046-7055.

Banke TG, Bowie D, Lee H, Huganir RL, Schousboe A, Traynelis SF (2000) Control of GluR1 AMPA receptor function by cAMP-dependent protein kinase. J Neurosci 20:89-102.

Barria A, Muller D, Derkach V, Griffith LC, Soderling TR (1997) Regulatory phosphorylation of AMPA-type glutamate receptors by CaM-KII during long-term potentiation. Science 276:2042-2045.

Bats C, Groc L, Choquet D (2007) The interaction between Stargazin and PSD-95 regulates AMPA receptor surface trafficking. Neuron 53:719-734.

Beattie EC, Carroll RC, Yu X, Morishita W, Yasuda H, von Zastrow M, Malenka RC (2000) Regulation of AMPA receptor endocytosis by a signaling mechanism shared with LTD. Nat Neurosci 3: 1291-1300.

Beffert U, Morfini G, Bock HH, Reyna H, Brady ST, Herz J (2002) Reelin-mediated signaling locally regulates protein kinase B/Akt and glycogen synthase kinase 3 $\beta$. J Biol Chem 277:49958-49964.

Beffert U, Weeber EJ, Durudas A, Qiu S, Masiulis I, Sweatt JD, Li WP, Adelmann G, Frotscher M, Hammer RE, Herz J (2005) Modulation of synaptic plasticity and memory by Reelin involves differential splicing of the lipoprotein receptor Apoer2. Neuron 47:567-579.
Beique JC, Lin DT, Kang MG, Aizawa H, Takamiya K, Huganir RL (2006) Synapse-specific regulation of AMPA receptor function by PSD-95. Proc Natl Acad Sci U S A 103:19535-19540.

Beneyto M, Meador-Woodruff JH (2004) Expression of transcripts encoding AMPA receptor subunits and associated postsynaptic proteins in the macaque brain. J Comp Neurol 468:530-554.

Benke TA, Luthi A, Isaac JT, Collingridge GL (1998) Modulation of AMPA receptor unitary conductance by synaptic activity. Nature 393:793-797.

Blanpied TA, Scott DB, Ehlers MD (2002) Dynamics and regulation of clathrin coats at specialized endocytic zones of dendrites and spines. Neuron 36:435-449.

Bliss T, Errington M, Fransen E, Godfraind JM, Kauer JA, Kooy RF, Maness PF, Furley AJ (2000) Long-term potentiation in mice lacking the neural cell adhesion molecule L1. Curr Biol 10:1607-1610.

Boehm J, Kang MG, Johnson RC, Esteban J, Huganir RL, Malinow R (2006) Synaptic incorporation of AMPA receptors during LTP is controlled by a PKC phosphorylation site on GluR1. Neuron 51: 213-225.

Borgdorff AJ, Choquet D (2002) Regulation of AMPA receptor lateral movements. Nature 417:649-653.

Bozdagi O, Shan W, Tanaka H, Benson DL, Huntley GW (2000) Increasing numbers of synaptic puncta during late-phase LTP: $\mathrm{N}$-cadherin is synthesized, recruited to synaptic sites, and required for potentiation. Neuron 28:245-259.

Broutman G, Baudry M (2001) Involvement of the secretory pathway for AMPA receptors in NMDA-induced potentiation in hippocampus. J Neurosci 21:27-34.

Brown TC, Tran IC, Backos DS, Esteban JA (2005) NMDA receptordependent activation of the small GTPase Rab5 drives the removal of synaptic AMPA receptors during hippocampal LTD. Neuron 45:81-94.

Burgess DL, Davis CF, Gefrides LA, Noebels JL (1999) Identification of three novel $\mathrm{Ca}^{2+}$ channel gamma subunit genes reveals molecular diversification by tandem and chromosome duplication. Genome Res 9:1204-1213.

Caldeira MV, Melo CV, Pereira DB, Carvalho R, Correia SS, Backos DS, Carvalho AL, Esteban JA, Duarte CB (2007) Brain-derived neurotrophic factor regulates the expression and synaptic delivery of $\alpha$-amino-3-hydroxy-5-methyl-4-isoxazole propionic acid receptor subunits in hippocampal neurons. J Biol Chem 282:1261912628 .

Carroll RC, Beattie EC, von Zastrow M, Malenka RC (2001) Role of AMPA receptor endocytosis in synaptic plasticity. Nat Rev Neurosci 2:315-324

Carroll RC, Beattie EC, Xia H, Luscher C, Altschuler Y, Nicoll RA, Malenka RC, von Zastrow M (1999) Dynamin-dependent endocytosis of ionotropic glutamate receptors. Proc Natl Acad Sci U S A 96:14112-14117.

Carvalho AL, Caldeira MV, Santos SD, Duarte CB (2008) Role of BDNF at glutamatergic synapses. $\mathrm{Br} J$ Pharmacol 153: S310-S324.

Carvalho AL, Duarte CB, Carvalho AP (2000) Regulation of AMPA receptors by phosphorylation. Neurochem Res 25:1245-1255.

Carvalho AL, Kameyama K, Huganir RL (1999) Characterization of phosphorylation sites on the glutamate receptor 4 subunit of the AMPA receptors. J Neurosci 19:4748-4754.

Chan CS, Weeber EJ, Zong L, Fuchs E, Sweatt JD, Davis RL (2006) Beta 1-integrins are required for hippocampal AMPA receptordependent synaptic transmission, synaptic plasticity, and working memory. J Neurosci 26:223-232.

Chen L, Chetkovich DM, Petralia RS, Sweeney NT, Kawasaki Y, Wenthold RJ, Bredt DS, Nicoll RA (2000) Stargazin regulates synaptic targeting of AMPA receptors by two distinct mechanisms. Nature 408:936-943.

Chetkovich DM, Chen L, Stocker TJ, Nicoll RA, Bredt DS (2002) Phosphorylation of the postsynaptic density-95 (PSD-95)/discs large/zona occludens-1 binding site of stargazin regulates binding 
to PSD-95 and synaptic targeting of AMPA receptors. J Neurosci 22:5791-5796.

Chowdhury S, Shepherd JD, Okuno H, Lyford G, Petralia RS, Plath N, Kuhl D, Huganir RL, Worley PF (2006) Arc/Arg3.1 interacts with the endocytic machinery to regulate AMPA receptor trafficking. Neuron 52:445-459.

Chung HJ, Steinberg JP, Huganir RL, Linden DJ (2003) Requirement of AMPA receptor GluR2 phosphorylation for cerebellar long-term depression. Science 300:1751-1755.

Chung HJ, Xia J, Scannevin RH, Zhang X, Huganir RL (2000) Phosphorylation of the AMPA receptor subunit GluR2 differentially regulates its interaction with PDZ domain-containing proteins. J Neurosci 20:7258-7267.

Coleman SK, Moykkynen T, Cai C, von Ossowski L, Kuismanen E, Korpi ER, Keinanen K (2006) Isoform-specific early trafficking of AMPA receptor flip and flop variants. J Neurosci 26:11220-11229.

Collingridge GL, Isaac JT, Wang YT (2004) Receptor trafficking and synaptic plasticity. Nat Rev Neurosci 5:952-962.

Coppolino MG, Dedhar S (2000) Bi-directional signal transduction by integrin receptors. Int J Biochem Cell Biol 32:171-188.

Correia SS, Duarte CB, Faro CJ, Pires EV, Carvalho AL (2003) Protein kinase $\mathrm{C} \gamma$ associates directly with the GluR4 $\alpha$-amino-3-hydroxy5-methyl-4-isoxazole propionate receptor subunit. Effect on receptor phosphorylation. J Biol Chem 278:6307-6313.

Cottrell JR, Borok E, Horvath TL, Nedivi E (2004) CPG2: a brain- and synapse-specific protein that regulates the endocytosis of glutamate receptors. Neuron 44:677-690.

Cummings JA, Mulkey RM, Nicoll RA, Malenka RC (1996) $\mathrm{Ca}^{2+}$ signaling requirements for long-term depression in the hippocampus. Neuron 16:825-833.

D'Arcangelo G (2005) Apoer2: a reelin receptor to remember. Neuron 47:471-473

Daw MI, Chittajallu R, Bortolotto ZA, Dev KK, Duprat F, Henley JM, Collingridge GL, Isaac JT (2000) PDZ proteins interacting with C-terminal GluR2/3 are involved in a PKC-dependent regulation of AMPA receptors at hippocampal synapses. Neuron 28:873-886.

Derkach V, Barria A, Soderling TR (1999) $\mathrm{Ca}^{2+} /$ calmodulin-kinase II enhances channel conductance of $\alpha$-amino-3-hydroxy-5-methyl-4isoxazolepropionate type glutamate receptors. Proc Natl Acad Sci U S A 96:3269-3274.

Desai NS, Cudmore RH, Nelson SB, Turrigiano GG (2002) Critical periods for experience-dependent synaptic scaling in visual cortex. Nat Neurosci 5:783-789.

Dev KK, Nishimune A, Henley JM, Nakanishi S (1999) The protein kinase $\mathrm{C}$ alpha binding protein PICK1 interacts with short but not long form alternative splice variants of AMPA receptor subunits. Neuropharmacology 38:635-644.

Dodds DC, Omeis IA, Cushman SJ, Helms JA, Perin MS (1997) Neuronal pentraxin receptor, a novel putative integral membrane pentraxin that interacts with neuronal pentraxin 1 and 2 and taipoxin-associated calcium-binding protein 49. J Biol Chem 272:21488-21494.

Dong H, O'Brien RJ, Fung ET, Lanahan AA, Worley PF, Huganir RL (1997) GRIP: a synaptic PDZ domain-containing protein that interacts with AMPA receptors. Nature 386:279-284.

Eberwine J, Miyashiro K, Kacharmina JE, Job C (2001) Local translation of classes of mRNAs that are targeted to neuronal dendrites. Proc Natl Acad Sci U S A 98:7080-7085.

Ehlers MD (2000) Reinsertion or degradation of AMPA receptors determined by activity-dependent endocytic sorting. Neuron 28:511-525.

Ehlers MD, Heine M, Groc L, Lee MC, Choquet D (2007) Diffusional trapping of GluR1 AMPA receptors by input-specific synaptic activity. Neuron 54:447-460.

Ehrlich I, Malinow R (2004) Postsynaptic density 95 controls AMPA receptor incorporation during long-term potentiation and experience-driven synaptic plasticity. J Neurosci 24:916-927.
Elias GM, Funke L, Stein V, Grant SG, Bredt DS, Nicoll RA (2006) Synapse-specific and developmentally regulated targeting of AMPA receptors by a family of MAGUK scaffolding proteins. Neuron 52:307-320.

Empson RM, Buckby LE, Kraus M, Bates KJ, Crompton MR, Gundelfinger ED, Beesley PW (2006) The cell adhesion molecule neuroplastin-65 inhibits hippocampal long-term potentiation via a mitogen-activated protein kinase p38-dependent reduction in surface expression of GluR1-containing glutamate receptors. J Neurochem 99:850-860.

Esteban JA, Shi SH, Wilson C, Nuriya M, Huganir RL, Malinow R (2003a) PKA phosphorylation of AMPA receptor subunits controls synaptic trafficking underlying plasticity. Nat Neurosci 6:136-143.

Esteban JA (2003b) AMPA receptor trafficking: a road map for synaptic plasticity. Mol Interv 3:375-385.

Feig S, Lipton P (1993) Pairing the cholinergic agonist carbachol with patterned Schaffer collateral stimulation initiates protein synthesis in hippocampal CA1 pyramidal cell dendrites via a muscarinic, NMDA-dependent mechanism. J Neurosci 13:1010-1021.

Gallagher SM, Daly CA, Bear MF, Huber KM (2004) Extracellular signal-regulated protein kinase activation is required for metabotropic glutamate receptor-dependent long-term depression in hippocampal area CA1. J Neurosci 24:4859-4864.

Gallo V, Russell JT (1995) Excitatory amino acid receptors in glia: different subtypes for distinct functions? J Neurosci Res 42:1-8.

Gerges NZ, Backos DS, Esteban JA (2004) Local control of AMPA receptor trafficking at the postsynaptic terminal by a small GTPase of the Rab family. J Biol Chem 279:43870-43878.

Gerges NZ, Backos DS, Rupasinghe CN, Spaller MR, Esteban JA (2006) Dual role of the exocyst in AMPA receptor targeting and insertion into the postsynaptic membrane. EMBO J 25:1623-1634.

Giancotti FG, Ruoslahti E (1999) Integrin signaling. Science 285: 1028-1032.

Goel A, Jiang B, Xu LW, Song L, Kirkwood A, Lee HK (2006) Crossmodal regulation of synaptic AMPA receptors in primary sensory cortices by visual experience. Nat Neurosci 9:1001-1003.

Gomes AR, Correia SS, Esteban JA, Duarte CB, Carvalho AL (2007a) PKC anchoring to GluR4 AMPA receptor subunit modulates PKCdriven receptor phosphorylation and surface expression. Traffic 8:259-269.

Gomes AR, Ferreira JS, Paternain AV, Lerma J, Duarte CB, Carvalho AL (2007b) Characterization of alternatively spliced isoforms of AMPA receptor subunits encoding truncated receptors. Mol Cell Neurosci, in press.

Gomes AR, Cunha P, Nuriya M, Faro CJ, Huganir RL, Pires EV, Carvalho AL, Duarte CB (2004) Metabotropic glutamate and dopamine receptors co-regulate AMPA receptor activity through PKA in cultured chick retinal neurones: effect on GluR4 phosphorylation and surface expression. J Neurochem 90:673-682.

Gouaux E (2004) Structure and function of AMPA receptors. J Physiol 554:249-253.

Gray EE, Fink AE, Sarinana J, Vissel B, O'Dell TJ (2007) Long-term potentiation in the hippocampal CA1 region does not require insertion and activation of GluR2-lacking AMPA receptors. J Neurophysiol 98:2488-2492.

Greger IH, Akamine P, Khatri L, Ziff EB (2006) Developmentally regulated, combinatorial RNA processing modulates AMPA receptor biogenesis. Neuron 51:85-97.

Greger IH, Esteban JA (2007) AMPA receptor biogenesis and trafficking. Curr Opin Neurobiol 17:289-297.

Greger IH, Khatri L, Kong X, Ziff EB (2003) AMPA receptor tetramerization is mediated by Q/R editing. Neuron 40:763-774.

Greger IH, Khatri L, Ziff EB (2002) RNA editing at arg607 controls AMPA receptor exit from the endoplasmic reticulum. Neuron 34:759-772.

Groc L, Choquet D (2006) AMPA and NMDA glutamate receptor trafficking: multiple roads for reaching and leaving the synapse. Cell Tissue Res 326:423-438. 
Groc L, Heine M, Cognet L, Brickley K, Stephenson FA, Lounis B, Choquet D (2004) Differential activity-dependent regulation of the lateral mobilities of AMPA and NMDA receptors. Nat Neurosci 7:695-696.

Grooms SY, Noh KM, Regis R, Bassell GJ, Bryan MK, Carroll RC, Zukin RS (2006) Activity bidirectionally regulates AMPA receptor mRNA abundance in dendrites of hippocampal neurons. J Neurosci 26:8339-8351.

Guzowski JF, Timlin JA, Roysam B, McNaughton BL, Worley PF, Barnes CA (2005) Mapping behaviorally relevant neural circuits with immediate-early gene expression. Curr Opin Neurobiol 15: $599-606$.

Hanley JG, Henley JM (2005) PICK1 is a calcium-sensor for NMDAinduced AMPA receptor trafficking. EMBO J 24:3266-3278.

Hanley JG, Khatri L, Hanson PI, Ziff EB (2002) NSF ATPase and $\alpha-/ \beta$-SNAPs disassemble the AMPA receptor-PICK1 complex. Neuron 34:53-67.

Hansel C, Linden DJ, D'Angelo E (2001) Beyond parallel fiber LTD: the diversity of synaptic and non-synaptic plasticity in the cerebellum. Nat Neurosci 4:467-475.

Harms KJ, Tovar KR, Craig AM (2005) Synapse-specific regulation of AMPA receptor subunit composition by activity. J Neurosci 25:6379-6388.

Hayashi T, Huganir RL (2004) Tyrosine phosphorylation and regulation of the AMPA receptor by SRC family tyrosine kinases. J Neurosci 24:6152-6160.

Hayashi T, Rumbaugh G, Huganir RL (2005) Differential regulation of AMPA receptor subunit trafficking by palmitoylation of two distinct sites. Neuron 47:709-723.

Hayashi Y, Shi SH, Esteban JA, Piccini A, Poncer JC, Malinow R (2000) Driving AMPA receptors into synapses by LTP and CaMKII: requirement for GluR1 and PDZ domain interaction. Science 287:2262-2267.

Hirai H, Launey T, Mikawa S, Torashima T, Yanagihara D, Kasaura T, Miyamoto A, Yuzaki M (2003) New role of $\delta 2$-glutamate receptors in AMPA receptor trafficking and cerebellar function. Nat Neurosci 6:869-876.

Hirai H, Matsuda S (1999) Interaction of the C-terminal domain of delta glutamate receptor with spectrin in the dendritic spines of cultured Purkinje cells. Neurosci Res 34:281-287.

Hirai H, Miyazaki T, Kakegawa W, Matsuda S, Mishina M, Watanabe M, Yuzaki M (2005) Rescue of abnormal phenotypes of the $\delta 2$ glutamate receptor-null mice by mutant $\delta 2$ transgenes. EMBO Rep 6:90-95.

Hirano T (2006) Cerebellar regulation mechanisms learned from studies on GluR82. Mol Neurobiol 33:1-16.

Hirano T, Kasono K, Araki K, Mishina M (1995) Suppression of LTD in cultured Purkinje cells deficient in the glutamate receptor $\delta 2$ subunit. Neuroreport 6:524-526.

Hirano T, Kasono K, Araki K, Shinozuka K, Mishina M (1994) Involvement of the glutamate receptor $\delta 2$ subunit in the long-term depression of glutamate responsiveness in cultured rat Purkinje cells. Neurosci Lett 182:172-176.

Hironaka K, Umemori H, Tezuka T, Mishina M, Yamamoto T (2000) The protein-tyrosine phosphatase PTPMEG interacts with glutamate receptor $\delta 2$ and $\varepsilon$ subunits. J Biol Chem 275:16167-16173.

Hollmann M, Heinemann S (1994) Cloned glutamate receptors. Annu Rev Neurosci 17:31-108.

Hsieh H, Boehm J, Sato C, Iwatsubo T, Tomita T, Sisodia S, Malinow $\mathrm{R}$ (2006) AMPAR removal underlies Abeta-induced synaptic depression and dendritic spine loss. Neuron 52:831-843.

Huang CC, You JL, Wu MY, Hsu KS (2004) Rap1-induced p38 mitogen-activated protein kinase activation facilitates AMPA receptor trafficking via the GDI.Rab5 complex. Potential role in (S)-3,5dihydroxyphenylglycene-induced long term depression. J Biol Chem 279:12286-12292.

Huang Z, Shimazu K, Woo NH, Zang K, Muller U, Lu B, Reichardt LF (2006) Distinct roles of the beta 1-class integrins at the developing and the mature hippocampal excitatory synapse. J Neurosci 26:11208-11219.

Huber KM, Kayser MS, Bear MF (2000) Role for rapid dendritic protein synthesis in hippocampal mGluR-dependent long-term depression. Science 288:1254-1257.

Ito M (1989) Long-term depression. Annu Rev Neurosci 12:85-102.

Ito M (2001) Cerebellar long-term depression: characterization, signal transduction, and functional roles. Physiol Rev 81:1143-1195.

Ito $\mathrm{M}$ (2002) Historical review of the significance of the cerebellum and the role of Purkinje cells in motor learning. Ann N Y Acad Sci 978:273-288.

Janssens N, Lesage AS (2001) Glutamate receptor subunit expression in primary neuronal and secondary glial cultures. J Neurochem 77:1457-1474.

Jeromin A, Huganir RL, Linden DJ (1996) Suppression of the glutamate receptor $\delta 2$ subunit produces a specific impairment in cerebellar long-term depression. J Neurophysiol 76:3578-3583.

Jia Z, Agopyan N, Miu P, Xiong Z, Henderson J, Gerlai R, Taverna FA, Velumian A, MacDonald J, Carlen P, Abramow-Newerly W, Roder $J$ (1996) Enhanced LTP in mice deficient in the AMPA receptor GluR2. Neuron 17:945-956.

Jin W, Ge WP, Xu J, Cao M, Peng L, Yung W, Liao D, Duan S, Zhang M, Xia J (2006) Lipid binding regulates synaptic targeting of PICK1, AMPA receptor trafficking, and synaptic plasticity. J Neurosci 26:2380-2390.

Jonas P (2000) The time course of signaling at central glutamatergic synapses. News Physiol Sci 15:83-89.

Ju W, Morishita W, Tsui J, Gaietta G, Deerinck TJ, Adams SR, Garner CC, Tsien RY, Ellisman MH, Malenka RC (2004) Activity-dependent regulation of dendritic synthesis and trafficking of AMPA receptors. Nat Neurosci 7:244-253.

Kacharmina JE, Job C, Crino P, Eberwine J (2000) Stimulation of glutamate receptor protein synthesis and membrane insertion within isolated neuronal dendrites. Proc Natl Acad Sci U S A 97:11545-11550.

Kakegawa W, Kohda K, Yuzaki M (2007) The $\delta 2$ 'ionotropic' glutamate receptor functions as a non-ionotropic receptor to control cerebellar synaptic plasticity. J Physiol 584:89-96.

Kano M, Kato M (1987) Quisqualate receptors are specifically involved in cerebellar synaptic plasticity. Nature 325:276-279.

Kashiwabuchi N, Ikeda K, Araki K, Hirano T, Shibuki K, Takayama C, Inoue Y, Kutsuwada T, Yagi T, Kang Y, et al. (1995) Impairment of motor coordination, Purkinje cell synapse formation, and cerebellar long-term depression in GluR $\delta 2$ mutant mice. Cell 81:245-252.

Keinanen K, Wisden W, Sommer B, Werner P, Herb A, Verdoorn TA, Sakmann B, Seeburg PH (1990) A family of AMPA-selective glutamate receptors. Science 249:556-560.

Kew JN, Kemp JA (2005) lonotropic and metabotropic glutamate receptor structure and pharmacology. Psychopharmacology (Berl) 179:4-29.

Kim CH, Chung HJ, Lee HK, Huganir RL (2001) Interaction of the AMPA receptor subunit GluR2/3 with PDZ domains regulates hippocampal long-term depression. Proc Natl Acad Sci U S A 98:11725-11730.

Kim CH, Takamiya K, Petralia RS, Sattler R, Yu S, Zhou W, Kalb R, Wenthold R, Huganir R (2005) Persistent hippocampal CA1 LTP in mice lacking the C-terminal PDZ ligand of GluR1. Nat Neurosci 8:985-987.

Kim E, Sheng M (2004) PDZ domain proteins of synapses. Nat Rev Neurosci 5:771-781.

Kim MJ, Futai K, Jo J, Hayashi Y, Cho K, Sheng M (2007) Synaptic accumulation of PSD-95 and synaptic function regulated by phosphorylation of serine-295 of PSD-95. Neuron 56:488-502.

Kina SI, Tezuka T, Kusakawa S, Kishimoto Y, Kakizawa S, Hashimoto K, Ohsugi M, Kiyama Y, Horai R, Sudo K, Kakuta S, Iwakura Y, lino M, Kano M, Manabe T, Yamamoto T (2007) Involvement of proteintyrosine phosphatase PTPMEG in motor learning and cerebellar long-term depression. Eur J Neurosci 26:2269-2278. 
Klugbauer N, Dai S, Specht V, Lacinova L, Marais E, Bohn G, Hofmann $F(2000)$ A family of $\gamma$-like calcium channel subunits. FEBS Lett 470:189-197.

Kopec CD, Li B, Wei W, Boehm J, Malinow R (2006) Glutamate receptor exocytosis and spine enlargement during chemically induced long-term potentiation. J Neurosci 26:2000-2009.

Kopec CD, Real E, Kessels HW, Malinow R (2007) GluR1 links structural and functional plasticity at excitatory synapses. J Neurosci 27:13706-13718.

Korber C, Werner M, Hoffmann J, Sager C, Tietze M, Schmid SM, Kott $S$, Hollmann M (2007) Stargazin interaction with $\alpha$-amino-3hydroxy-5-methyl-4-isoxazole propionate (AMPA) receptors is critically dependent on the amino acid at the narrow constriction of the ion channel. J Biol Chem 282:18758-18766.

Kramar EA, Bernard JA, Gall CM, Lynch G (2003) Integrins modulate fast excitatory transmission at hippocampal synapses. J Biol Chem 278:10722-10730.

Kramar EA, Lin B, Rex CS, Gall CM, Lynch G (2006) Integrin-driven actin polymerization consolidates long-term potentiation. Proc Natl Acad Sci U S A 103:5579-5584.

Kwak S, Weiss JH (2006) Calcium-permeable AMPA channels in neurodegenerative disease and ischemia. Curr Opin Neurobiol 16:281-287.

Landsend AS, Amiry-Moghaddam M, Matsubara A, Bergersen L, Usami S, Wenthold RJ, Ottersen OP (1997) Differential localization of delta glutamate receptors in the rat cerebellum: coexpression with AMPA receptors in parallel fiber-spine synapses and absence from climbing fiber-spine synapses. J Neurosci 17:834-842.

Laube B, Kuhse J, Betz H (1998) Evidence for a tetrameric structure of recombinant NMDA receptors. J Neurosci 18:2954-2961.

Lee HK, Barbarosie M, Kameyama K, Bear MF, Huganir RL (2000) Regulation of distinct AMPA receptor phosphorylation sites during bidirectional synaptic plasticity. Nature 405:955-959.

Lee HK, Min SS, Gallagher M, Kirkwood A (2005) NMDA receptorindependent long-term depression correlates with successful aging in rats. Nat Neurosci 8:1657-1659.

Lee HK, Takamiya K, Han JS, Man H, Kim CH, Rumbaugh G, Yu S, Ding L, He C, Petralia RS, Wenthold RJ, Gallagher M, Huganir RL (2003) Phosphorylation of the AMPA receptor GluR1 subunit is required for synaptic plasticity and retention of spatial memory. Cell 112:631-643.

Lee HK, Takamiya K, Kameyama K, He K, Yu S, Rossetti L, Wilen D, Huganir RL (2007) Identification and characterization of a novel phosphorylation site on the GluR1 subunit of AMPA receptors. Mol Cell Neurosci 36:86-94.

Lee SH, Liu L, Wang YT, Sheng M (2002) Clathrin adaptor AP2 and NSF interact with overlapping sites of GluR2 and play distinct roles in AMPA receptor trafficking and hippocampal LTD. Neuron 36:661-674.

Leonard AS, Davare MA, Horne MC, Garner CC, Hell JW (1998) SAP97 is associated with the $\alpha$-amino-3-hydroxy-5-methylisoxazole-4-propionic acid receptor GluR1 subunit. J Biol Chem 273:19518-19524.

Liao D, Zhang X, O'Brien R, Ehlers MD, Huganir RL (1999) Regulation of morphological postsynaptic silent synapses in developing hippocampal neurons. Nat Neurosci 2:37-43.

Lin DT, Huganir RL (2007) PICK1 and phosphorylation of the glutamate receptor 2 (GluR2) AMPA receptor subunit regulates GluR2 recycling after NMDA receptor-induced internalization. J Neurosci 27:13903-13908.

Lin JW, Ju W, Foster K, Lee SH, Ahmadian G, Wyszynski M, Wang YT, Sheng M (2000) Distinct molecular mechanisms and divergent endocytotic pathways of AMPA receptor internalization. Nat Neurosci 3:1282-1290.

Lin SC, Bergles DE (2004) Synaptic signaling between neurons and glia. Glia 47:290-298.

Lissin DV, Gomperts SN, Carroll RC, Christine CW, Kalman D, Kitamura M, Hardy S, Nicoll RA, Malenka RC, von Zastrow M (1998)
Activity differentially regulates the surface expression of synaptic AMPA and NMDA glutamate receptors. Proc Natl Acad Sci U S A 95:7097-7102.

Liu B, Liao M, Mielke JG, Ning K, Chen Y, Li L, El-Hayek YH, Gomez E, Zukin RS, Fehlings MG, Wan Q (2006) Ischemic insults direct glutamate receptor subunit 2-lacking AMPA receptors to synaptic sites. J Neurosci 26:5309-5319.

Lledo PM, Zhang X, Sudhof TC, Malenka RC, Nicoll RA (1998) Postsynaptic membrane fusion and long-term potentiation. Science 279:399-403.

Lu J, Helton TD, Blanpied TA, Racz B, Newpher TM, Weinberg RJ, Ehlers MD (2007a) Postsynaptic positioning of endocytic zones and AMPA receptor cycling by physical coupling of dynamin-3 to Homer. Neuron 55:874-889.

Lu Y, Allen M, Halt AR, Weisenhaus M, Dallapiazza RF, Hall DD, Usachev YM, McKnight GS, Hell JW (2007b) Age-dependent requirement of AKAP150-anchored PKA and GluR2-lacking AMPA receptors in LTP. EMBO J 26:4879-4890.

Lu W, Man H, Ju W, Trimble WS, MacDonald JF, Wang YT (2001) Activation of synaptic NMDA receptors induces membrane insertion of new AMPA receptors and LTP in cultured hippocampal neurons. Neuron 29:243-254.

Luscher C, Xia H, Beattie EC, Carroll RC, von Zastrow M, Malenka RC, Nicoll RA (1999) Role of AMPA receptor cycling in synaptic transmission and plasticity. Neuron 24:649-658.

Ly CD, Roche KW, Lee HK, Wenthold RJ (2002) Identification of rat EMAP, a $\delta$-glutamate receptor binding protein. Biochem Biophys Res Commun 291:85-90.

Madden DR (2002) The structure and function of glutamate receptor ion channels. Nat Rev Neurosci 3:91-101.

Malinow R, Mainen ZF, Hayashi Y (2000) LTP mechanisms: from silence to four-lane traffic. Curr Opin Neurobiol 10:352-357.

Mammen AL, Kameyama K, Roche KW, Huganir RL (1997) Phosphorylation of the $\alpha$-amino-3-hydroxy-5-methylisoxazole4-propionic acid receptor GluR1 subunit by calcium/calmodulin-dependent kinase II. J Biol Chem 272:32528-32533.

Man HY, Lin JW, Ju WH, Ahmadian G, Liu L, Becker LE, Sheng M, Wang YT (2000) Regulation of AMPA receptor-mediated synaptic transmission by clathrin-dependent receptor internalization. Neuron 25:649-662.

Man HY, Wang Q, Lu WY, Ju W, Ahmadian G, Liu L, D'Souza S, Wong TP, Taghibiglou C, Lu J, Becker LE, Pei L, Liu F, Wymann MP, MacDonald JF, Wang YT (2003) Activation of PI3-kinase is required for AMPA receptor insertion during LTP of mEPSCs in cultured hippocampal neurons. Neuron 38:611-624.

Mano I, Teichberg VI (1998) A tetrameric subunit stoichiometry for a glutamate receptor-channel complex. Neuroreport 9:327-331.

Martin KC, Zukin RS (2006) RNA trafficking and local protein synthesis in dendrites: an overview. J Neurosci 26:7131-7134.

Martin LJ, Blackstone CD, Levey Al, Huganir RL, Price DL (1993) AMPA glutamate receptor subunits are differentially distributed in rat brain. Neuroscience 53:327-358.

Martin SJ, Grimwood PD, Morris RG (2000) Synaptic plasticity and memory: an evaluation of the hypothesis. Annu Rev Neurosci 23:649-711.

Matsuda S, Launey T, Mikawa S, Hirai H (2000) Disruption of AMPA receptor GluR2 clusters following long-term depression induction in cerebellar Purkinje neurons. EMBO J 19:2765-2774.

Matsuda S, Mikawa S, Hirai H (1999) Phosphorylation of serine-880 in GluR2 by protein kinase $C$ prevents its $C$ terminus from binding with glutamate receptor-interacting protein. J Neurochem 73: 1765-1768.

Matsuzaki M, Ellis-Davies GC, Nemoto T, Miyashita Y, lino M, Kasai H (2001) Dendritic spine geometry is critical for AMPA receptor expression in hippocampal CA1 pyramidal neurons. Nat Neurosci 4:1086-1092. 
Matsuzaki M, Honkura N, Ellis-Davies GC, Kasai H (2004) Structural basis of long-term potentiation in single dendritic spines. Nature 429:761-766.

Mayer ML (2005) Glutamate receptor ion channels. Curr Opin Neurobiol 15:282-288.

Menuz K, Stroud RM, Nicoll RA, Hays FA (2007) TARP auxiliary subunits switch AMPA receptor antagonists into partial agonists. Science 318:815-817.

Migaud M, Charlesworth P, Dempster M, Webster LC, Watabe AM, Makhinson M, He Y, Ramsay MF, Morris RG, Morrison JH, O'Dell TJ, Grant SG (1998) Enhanced long-term potentiation and impaired learning in mice with mutant postsynaptic density-95 protein. Nature 396:433-439.

Miyagi $\mathrm{Y}$, Yamashita T, Fukaya M, Sonoda T, Okuno T, Yamada $\mathrm{K}$, Watanabe M, Nagashima Y, Aoki I, Okuda K, Mishina M, Kawamoto S (2002) Delphilin: a novel PDZ and formin homology domain-containing protein that synaptically colocalizes and interacts with glutamate receptor $\delta 2$ subunit. J Neurosci 22:803-814.

Morris RG (2006) Elements of a neurobiological theory of hippocampal function: the role of synaptic plasticity, synaptic tagging and schemas. Eur J Neurosci 23:2829-2846.

Mosbacher J, Schoepfer R, Monyer H, Burnashev N, Seeburg PH, Ruppersberg JP (1994) A molecular determinant for submillisecond desensitization in glutamate receptors. Science 266:10591062.

Moult PR, Gladding CM, Sanderson TM, Fitzjohn SM, Bashir ZI, Molnar E, Collingridge GL (2006) Tyrosine phosphatases regulate AMPA receptor trafficking during metabotropic glutamate receptormediated long-term depression. J Neurosci 26:2544-2554.

Moult PR, Schnabel R, Kilpatrick IC, Bashir ZI, Collingridge GL (2002) Tyrosine dephosphorylation underlies DHPG-induced LTD. Neuropharmacology 43:175-180.

Mulkey RM, Endo S, Shenolikar S, Malenka RC (1994) Involvement of a calcineurin/inhibitor-1 phosphatase cascade in hippocampal long-term depression. Nature 369:486-488.

Mulkey RM, Herron CE, Malenka RC (1993) An essential role for protein phosphatases in hippocampal long-term depression. Science 261:1051-1055.

Muller D, Wang C, Skibo G, Toni N, Cremer H, Calaora V, Rougon G, Kiss JZ (1996) PSA-NCAM is required for activity-induced synaptic plasticity. Neuron 17:413-422.

Murai KK, Misner D, Ranscht B (2002) Contactin supports synaptic plasticity associated with hippocampal long-term depression but not potentiation. Curr Biol 12:181-190.

Murase S, Mosser E, Schuman EM (2002) Depolarization drives betacatenin into neuronal spines promoting changes in synaptic structure and function. Neuron 35:91-105.

Nakamura K, Manabe T, Watanabe M, Mamiya T, Ichikawa R, Kiyama Y, Sanbo M, Yagi T, Inoue Y, Nabeshima T, Mori H, Mishina M (2001) Enhancement of hippocampal LTP, reference memory and sensorimotor gating in mutant mice lacking a telencephalon-specific cell adhesion molecule. Eur J Neurosci 13:179-189.

Nicoll RA, Tomita S, Bredt DS (2006) Auxiliary subunits assist AMPAtype glutamate receptors. Science 311:1253-1256.

Nimpf J, Schneider WJ (2000) From cholesterol transport to signal transduction: low density lipoprotein receptor, very low density lipoprotein receptor, and apolipoprotein E receptor-2. Biochim Biophys Acta 1529:287-298.

Nishimune A, Isaac JT, Molnar E, Noel J, Nash SR, Tagaya M, Collingridge GL, Nakanishi S, Henley JM (1998) NSF binding to GluR2 regulates synaptic transmission. Neuron 21:87-97.

Noel J, Ralph GS, Pickard L, Williams J, Molnar E, Uney JB, Collingridge GL, Henley JM (1999) Surface expression of AMPA receptors in hippocampal neurons is regulated by an NSF-dependent mechanism. Neuron 23:365-376.

Nosten-Bertrand M, Errington ML, Murphy KP, Tokugawa Y, Barboni E, Kozlova E, Michalovich D, Morris RG, Silver J, Stewart CL, Bliss
TV, Morris RJ (1996) Normal spatial learning despite regional inhibition of LTP in mice lacking Thy-1. Nature 379:826-829.

Nuriya M, Huganir RL (2006) Regulation of AMPA receptor trafficking by N-cadherin. J Neurochem 97:652-661.

O'Brien RJ, Kamboj S, Ehlers MD, Rosen KR, Fischbach GD, Huganir RL (1998) Activity-dependent modulation of synaptic AMPA receptor accumulation. Neuron 21:1067-1078.

O'Brien RJ, Xu D, Petralia RS, Steward O, Huganir RL, Worley P (1999) Synaptic clustering of AMPA receptors by the extracellular immediate-early gene product Narp. Neuron 23:309-323.

Oh MC, Derkach VA (2005) Dominant role of the GluR2 subunit in regulation of AMPA receptors by CaMKII. Nat Neurosci 8:853854.

Oh MC, Derkach VA, Guire ES, Soderling TR (2006) Extrasynaptic membrane trafficking regulated by GluR1 serine 845 phosphorylation primes AMPA receptors for long-term potentiation. J Biol Chem 281:752-758.

Oliet SH, Malenka RC, Nicoll RA (1997) Two distinct forms of longterm depression coexist in CA1 hippocampal pyramidal cells. Neuron 18:969-982.

Osten P, Khatri L, Perez JL, Kohr G, Giese G, Daly C, Schulz TW, Wensky A, Lee LM, Ziff EB (2000) Mutagenesis reveals a role for ABP/GRIP binding to GluR2 in synaptic surface accumulation of the AMPA receptor. Neuron 27:313-325.

Osten P, Srivastava S, Inman GJ, Vilim FS, Khatri L, Lee LM, States BA, Einheber S, Milner TA, Hanson PI, Ziff EB (1998) The AMPA receptor GluR2 C terminus can mediate a reversible, ATP-dependent interaction with NSF and $\alpha$ - and $\beta$-SNAPs. Neuron 21: 99-110.

Osten P, Stern-Bach Y (2006) Learning from stargazin: the mouse, the phenotype and the unexpected. Curr Opin Neurobiol 16:275-280.

Ostroff LE, Fiala JC, Allwardt B, Harris KM (2002) Polyribosomes redistribute from dendritic shafts into spines with enlarged synapses during LTP in developing rat hippocampal slices. Neuron 35:535-545.

Ozawa S, Kamiya H, Tsuzuki K (1998) Glutamate receptors in the mammalian central nervous system. Prog Neurobiol 54:581-618.

Palmer CL, Lim W, Hastie PG, Toward M, Korolchuk VI, Burbidge SA, Banting G, Collingridge GL, Isaac JT, Henley JM (2005a) Hippocalcin functions as a calcium sensor in hippocampal LTD. Neuron 47:487-494.

Palmer CL, Cotton L, Henley JM (2005b) The molecular pharmacology and cell biology of $\alpha$-amino-3-hydroxy-5-methyl-4-isoxazolepropionic acid receptors. Pharmacol Rev 57:253-277.

Palmer MJ, Irving AJ, Seabrook GR, Jane DE, Collingridge GL (1997) The group I mGlu receptor agonist DHPG induces a novel form of LTD in the CA1 region of the hippocampus. Neuropharmacology 36:1517-1532.

Park M, Penick EC, Edwards JG, Kauer JA, Ehlers MD (2004) Recycling endosomes supply AMPA receptors for LTP. Science 305:1972-1975.

Park M, Salgado JM, Ostroff L, Helton TD, Robinson CG, Harris KM, Ehlers MD (2006) Plasticity-induced growth of dendritic spines by exocytic trafficking from recycling endosomes. Neuron 52:817830.

Passafaro M, Nakagawa T, Sala C, Sheng M (2003) Induction of dendritic spines by an extracellular domain of AMPA receptor subunit GluR2. Nature 424:677-681.

Passafaro M, Piech V, Sheng M (2001) Subunit-specific temporal and spatial patterns of AMPA receptor exocytosis in hippocampal neurons. Nat Neurosci 4:917-926.

Pastalkova E, Serrano P, Pinkhasova D, Wallace E, Fenton AA, Sacktor TC (2006) Storage of spatial information by the maintenance mechanism of LTP. Science 313:1141-1144.

Perez JL, Khatri L, Chang C, Srivastava S, Osten P, Ziff EB (2001) PICK1 targets activated protein kinase $\mathrm{C} \alpha$ to AMPA receptor clusters in spines of hippocampal neurons and reduces surface levels 
of the AMPA-type glutamate receptor subunit 2. J Neurosci 21:5417-5428.

Petralia RS, Rubio ME, Wenthold RJ (1999) Cellular and subcellular distribution of glutamate receptors. In: Ionotropic glutamate receptors in the CNS (Jonas $\mathrm{P}$, Monyer $\mathrm{H}$, eds). Heidelberg: Springer-Verlag.

Petralia RS, Wang YX, Wenthold RJ (2003) Internalization at glutamatergic synapses during development. Eur J Neurosci 18: 3207-3217.

Petralia RS, Wenthold RJ (1992) Light and electron immunocytochemical localization of AMPA-selective glutamate receptors in the rat brain. J Comp Neurol 318:329-354.

Pettit DL, Perlman S, Malinow R (1994) Potentiated transmission and prevention of further LTP by increased CaMKII activity in postsynaptic hippocampal slice neurons. Science 266:1881-1885.

Piccini A, Malinow R (2002) Critical postsynaptic density 95/disc large/ zonula occludens-1 interactions by glutamate receptor 1 (GluR1) and GluR2 required at different subcellular sites. J Neurosci 22:5387-5392.

Plant K, Pelkey KA, Bortolotto ZA, Morita D, Terashima A, McBain CJ, Collingridge GL, Isaac JT (2006) Transient incorporation of native GluR2-lacking AMPA receptors during hippocampal long-term potentiation. Nat Neurosci 9:602-604.

Plath N, Ohana O, Dammermann B, Errington ML, Schmitz D, Gross C, Mao X, Engelsberg A, Mahlke C, Welzl H, Kobalz U, Stawrakakis A, Fernandez E, Waltereit R, Bick-Sander A, Therstappen E, Cooke SF, Blanquet V, Wurst W, Salmen B, BosI MR, Lipp HP, Grant SG, Bliss TV, Wolfer DP, Kuhl D (2006) Arc/Arg3.1 is essential for the consolidation of synaptic plasticity and memories. Neuron 52:437-444.

Priel A, Kolleker A, Ayalon G, Gillor M, Osten P, Stern-Bach Y (2005) Stargazin reduces desensitization and slows deactivation of the AMPA-type glutamate receptors. J Neurosci 25:2682-2686.

Qin Y, Zhu Y, Baumgart JP, Stornetta RL, Seidenman K, Mack V, van Aelst L, Zhu JJ (2005) State-dependent Ras signaling and AMPA receptor trafficking. Genes Dev 19:2000-2015.

Qiu S, Zhao LF, Korwek KM, Weeber EJ (2006) Differential reelininduced enhancement of NMDA and AMPA receptor activity in the adult hippocampus. J Neurosci 26:12943-12955.

Racz B, Blanpied TA, Ehlers MD, Weinberg RJ (2004) Lateral organization of endocytic machinery in dendritic spines. Nat Neurosci 7:917-918.

Rial Verde EM, Lee-Osbourne J, Worley PF, Malinow R, Cline HT (2006) Increased expression of the immediate-early gene arc/ arg3.1 reduces AMPA receptor-mediated synaptic transmission. Neuron 52:461-474.

Roche KW, Ly CD, Petralia RS, Wang YX, McGee AW, Bredt DS, Wenthold RJ (1999) Postsynaptic density-93 interacts with the $\delta 2$ glutamate receptor subunit at parallel fiber synapses. J Neurosci 19:3926-3934.

Roche KW, O'Brien RJ, Mammen AL, Bernhardt J, Huganir RL (1996) Characterization of multiple phosphorylation sites on the AMPA receptor GluR1 subunit. Neuron 16:1179-1188.

Rosenmund C, Stern-Bach Y, Stevens CF (1998) The tetrameric structure of a glutamate receptor channel. Science 280:15961599

Rothman JE (1994) Intracellular membrane fusion. Adv Second Messenger Phosphoprotein Res 29:81-96.

Rouach N, Byrd K, Petralia RS, Elias GM, Adesnik H, Tomita S, Karimzadegan S, Kealey C, Bredt DS, Nicoll RA (2005) TARP gamma-8 controls hippocampal AMPA receptor number, distribution and synaptic plasticity. Nat Neurosci 8:1525-1533.

Rumpel S, LeDoux J, Zador A, Malinow R (2005) Postsynaptic receptor trafficking underlying a form of associative learning. Science 308:83-88.

Rutherford LC, Nelson SB, Turrigiano GG (1998) BDNF has opposite effects on the quantal amplitude of pyramidal neuron and interneuron excitatory synapses. Neuron 21:521-530.
Saglietti L, Dequidt C, Kamieniarz K, Rousset MC, Valnegri $P$, Thoumine O, Beretta F, Fagni L, Choquet D, Sala C, Sheng M, Passafaro M (2007) Extracellular interactions between GluR2 and $\mathrm{N}$-cadherin in spine regulation. Neuron 54:461-477.

Sans N, Racca C, Petralia RS, Wang YX, McCallum J, Wenthold RJ (2001) Synapse-associated protein 97 selectively associates with a subset of AMPA receptors early in their biosynthetic pathway. J Neurosci 21:7506-7516.

Schlimgen AK, Helms JA, Vogel H, Perin MS (1995) Neuronal pentraxin, a secreted protein with homology to acute phase proteins of the immune system. Neuron 14:519-526.

Schnell E, Sizemore M, Karimzadegan S, Chen L, Bredt DS, Nicoll RA (2002) Direct interactions between PSD-95 and stargazin control synaptic AMPA receptor number. Proc Natl Acad Sci U S A 99:13902-13907.

Schratt GM, Nigh EA, Chen WG, Hu L, Greenberg ME (2004) BDNF regulates the translation of a select group of mRNAs by a mammalian target of rapamycin-phosphatidylinositol 3-kinase-dependent pathway during neuronal development. J Neurosci 24: 7366-7377.

Schulz TW, Nakagawa T, Licznerski P, Pawlak V, Kolleker A, Rozov A, Kim J, Dittgen T, Kohr G, Sheng M, Seeburg PH, Osten P (2004) Actin $/ \alpha$-actinin-dependent transport of AMPA receptors in dendritic spines: role of the PDZ-LIM protein RIL. J Neurosci 24: 8584-8594.

Schuman EM, Dynes JL, Steward O (2006) Synaptic regulation of translation of dendritic mRNAs. J Neurosci 26:7143-7146.

Schwartz MA, Shattil SJ (2000) Signaling networks linking integrins and rho family GTPases. Trends Biochem Sci 25:388-391.

Seidenman KJ, Steinberg JP, Huganir R, Malinow R (2003) Glutamate receptor subunit 2 Serine 880 phosphorylation modulates synaptic transmission and mediates plasticity in CA1 pyramidal cells. J Neurosci 23:9220-9228.

Serulle Y, Zhang S, Ninan I, Puzzo D, McCarthy M, Khatri L, Arancio O, Ziff EB (2007) A GluR1-cGKII interaction regulates AMPA receptor trafficking. Neuron 56:670-688.

Sharma K, Fong DK, Craig AM (2006) Postsynaptic protein mobility in dendritic spines: long-term regulation by synaptic NMDA receptor activation. Mol Cell Neurosci 31:702-712.

Shen L, Liang F, Walensky LD, Huganir RL (2000) Regulation of AMPA receptor GluR1 subunit surface expression by a $4.1 \mathrm{~N}$-linked actin cytoskeletal association. J Neurosci 20:7932-7940.

Sheng M, Sala C (2001) PDZ domains and the organization of supramolecular complexes. Annu Rev Neurosci 24:1-29.

Shepherd JD, Rumbaugh G, Wu J, Chowdhury S, Plath N, Kuhl D, Huganir RL, Worley PF (2006) Arc/Arg3.1 mediates homeostatic synaptic scaling of AMPA receptors. Neuron 52:475-484.

Shi S, Hayashi Y, Esteban JA, Malinow R (2001) Subunit-specific rules governing AMPA receptor trafficking to synapses in hippocampal pyramidal neurons. Cell 105:331-343.

Shi SH, Hayashi Y, Petralia RS, Zaman SH, Wenthold RJ, Svoboda K, Malinow R (1999) Rapid spine delivery and redistribution of AMPA receptors after synaptic NMDA receptor activation. Science 284:1811-1816

Shukla K, Kim J, Blundell J, Powell CM (2007) Learning-induced glutamate receptor phosphorylation resembles that induced by long term potentiation. J Biol Chem 282:18100-18107.

Sia GM, Beique JC, Rumbaugh G, Cho R, Worley PF, Huganir RL (2007) Interaction of the N-terminal domain of the AMPA receptor GluR4 subunit with the neuronal pentraxin NP1 mediates GluR4 synaptic recruitment. Neuron 55:87-102.

Silverman JB, Restituito S, Lu W, Lee-Edwards L, Khatri L, Ziff EB (2007) Synaptic anchorage of AMPA receptors by cadherins through neural plakophilin-related arm protein AMPA receptorbinding protein complexes. J Neurosci 27:8505-8516.

Smith WB, Starck SR, Roberts RW, Schuman EM (2005) Dopaminergic stimulation of local protein synthesis enhances surface expres- 
sion of GluR1 and synaptic transmission in hippocampal neurons. Neuron 45:765-779.

Snyder EM, Philpot BD, Huber KM, Dong X, Fallon JR, Bear MF (2001) Internalization of ionotropic glutamate receptors in response to mGluR activation. Nat Neurosci 4:1079-1085.

Sommer B, Keinanen K, Verdoorn TA, Wisden W, Burnashev N, Herb A, Kohler M, Takagi T, Sakmann B, Seeburg PH (1990) Flip and flop: a cell-specific functional switch in glutamate-operated channels of the CNS. Science 249:1580-1585.

Sommer B, Kohler M, Sprengel R, Seeburg PH (1991) RNA editing in brain controls a determinant of ion flow in glutamate-gated channels. Cell 67:11-19.

Song I, Kamboj S, Xia J, Dong H, Liao D, Huganir RL (1998) Interaction of the $\mathrm{N}$-ethylmaleimide-sensitive factor with AMPA receptors. Neuron 21:393-400.

Spreafico R, Frassoni C, Arcelli P, Battaglia G, Wenthold RJ, De Biasi $S$ (1994) Distribution of AMPA selective glutamate receptors in the thalamus of adult rats and during postnatal development. A light and ultrastructural immunocytochemical study. Brain Res Dev Brain Res 82:231-244.

Srivastava S, Osten P, Vilim FS, Khatri L, Inman G, States B, Daly C, DeSouza S, Abagyan R, Valtschanoff JG, Weinberg RJ, Ziff EB (1998) Novel anchorage of GluR2/3 to the postsynaptic density by the AMPA receptor-binding protein ABP. Neuron 21:581-591.

Steinberg JP, Takamiya K, Shen Y, Xia J, Rubio ME, Yu S, Jin W, Thomas GM, Linden DJ, Huganir RL (2006) Targeted in vivo mutations of the AMPA receptor subunit GluR2 and its interacting protein PICK1 eliminate cerebellar long-term depression. Neuron 49:845-860

Stellwagen D, Malenka RC (2006) Synaptic scaling mediated by glial TNF- $\alpha$. Nature 440:1054-1059.

Steward O, Levy WB (1982) Preferential localization of polyribosomes under the base of dendritic spines in granule cells of the dentate gyrus. J Neurosci 2:284-291.

Steward O, Schuman EM (2003) Compartmentalized synthesis and degradation of proteins in neurons. Neuron 40:347-359.

Sun X, Zhao Y, Wolf ME (2005) Dopamine receptor stimulation modulates AMPA receptor synaptic insertion in prefrontal cortex neurons. J Neurosci 25:7342-7351.

Takeichi M (1990) Cadherins: a molecular family important in selective cell-cell adhesion. Annu Rev Biochem 59:237-252.

Talos DM, Follett PL, Folkerth RD, Fishman RE, Trachtenberg FL, Volpe JJ, Jensen FE (2006) Developmental regulation of $\alpha$-amino3-hydroxy-5-methyl-4-isoxazole-propionic acid receptor subunit expression in forebrain and relationship to regional susceptibility to hypoxic/ischemic injury. II. Human cerebral white matter and cortex. J Comp Neurol 497:61-77.

Tanaka H, Shan W, Phillips GR, Arndt K, Bozdagi O, Shapiro L, Huntley GW, Benson DL, Colman DR (2000) Molecular modification of $\mathrm{N}$-cadherin in response to synaptic activity. Neuron 25: 93-107.

Tang L, Hung CP, Schuman EM (1998) A role for the cadherin family of cell adhesion molecules in hippocampal long-term potentiation. Neuron 20:1165-1175.

Tang SJ, Schuman EM (2002) Protein synthesis in the dendrite. Philos Trans R Soc Lond B Biol Sci 357:521-529.

Tardin C, Cognet L, Bats C, Lounis B, Choquet D (2003) Direct imaging of lateral movements of AMPA receptors inside synapses. EMBO J 22:4656-4665.

Terashima A, Cotton L, Dev KK, Meyer G, Zaman S, Duprat F, Henley JM, Collingridge GL, Isaac JT (2004) Regulation of synaptic strength and AMPA receptor subunit composition by PICK1. J Neurosci 24:5381-5390.

Togashi H, Abe K, Mizoguchi A, Takaoka K, Chisaka O, Takeichi M (2002) Cadherin regulates dendritic spine morphogenesis. Neuron 35:77-89.

Tomita S, Chen L, Kawasaki Y, Petralia RS, Wenthold RJ, Nicoll RA, Bredt DS (2003) Functional studies and distribution define a family of transmembrane AMPA receptor regulatory proteins. J Cell Biol 161:805-816.

Tomita S, Stein V, Stocker TJ, Nicoll RA, Bredt DS (2005) Bidirectional synaptic plasticity regulated by phosphorylation of stargazin-like TARPs. Neuron 45:269-277.

Tsui CC, Copeland NG, Gilbert DJ, Jenkins NA, Barnes C, Worley PF (1996) Narp, a novel member of the pentraxin family, promotes neurite outgrowth and is dynamically regulated by neuronal activity. J Neurosci 16:2463-2478.

Turrigiano G (2007) Homeostatic signaling: the positive side of negative feedback. Curr Opin Neurobiol 17:318-324.

Turrigiano GG, Leslie KR, Desai NS, Rutherford LC, Nelson SB (1998) Activity-dependent scaling of quantal amplitude in neocortical neurons. Nature 391:892-896.

Uemura T, Mori H, Mishina M (2004) Direct interaction of GluR $\delta 2$ with Shank scaffold proteins in cerebellar Purkinje cells. Mol Cell Neurosci 26:330-341.

Vaithianathan T, Matthias K, Bahr B, Schachner M, Suppiramaniam V, Dityatev A, Steinhauser C (2004) Neural cell adhesion moleculeassociated polysialic acid potentiates $\alpha$-amino-3-hydroxy-5-methylisoxazole-4-propionic acid receptor currents. J Biol Chem 279:47975-47984.

Vandenberghe W, Nicoll RA, Bredt DS (2005) Interaction with the unfolded protein response reveals a role for stargazin in biosynthetic AMPA receptor transport. J Neurosci 25:1095-1102.

van der Flier A, Sonnenberg A (2001) Function and interactions of integrins. Cell Tissue Res 305:285-298.

Wang YT, Linden DJ (2000) Expression of cerebellar long-term depression requires postsynaptic clathrin-mediated endocytosis. Neuron 25:635-647.

Watkins JC, Davies J, Evans RH, Francis AA, Jones AW (1981) Pharmacology of receptors for excitatory amino acids. Adv Biochem Psychopharmacol 27:263-273.

Weeber EJ, Beffert U, Jones C, Christian JM, Forster E, Sweatt JD, Herz J (2002) Reelin and ApoE receptors cooperate to enhance hippocampal synaptic plasticity and learning. J Biol Chem 277:39944-39952.

Wenthold RJ, Petralia RS, Blahos J II, Niedzielski AS (1996) Evidence for multiple AMPA receptor complexes in hippocampal CA1/CA2 neurons. J Neurosci 16:1982-1989.

Whitlock JR, Heynen AJ, Shuler MG, Bear MF (2006) Learning induces long-term potentiation in the hippocampus. Science 313:1093-1097.

Williams JM, Guevremont D, Mason-Parker SE, Luxmanan C, Tate WP, Abraham WC (2007) Differential trafficking of AMPA and NMDA receptors during long-term potentiation in awake adult animals. J Neurosci 27:14171-14178.

Xia J, Zhang X, Staudinger J, Huganir RL (1999) Clustering of AMPA receptors by the synaptic PDZ domain-containing protein PICK1. Neuron 22:179-187.

Xiao MY, Zhou Q, Nicoll RA (2001) Metabotropic glutamate receptor activation causes a rapid redistribution of AMPA receptors. Neuropharmacology 41:664-671.

Xu D, Hopf C, Reddy R, Cho RW, Guo L, Lanahan A, Petralia RS, Wenthold RJ, O'Brien RJ, Worley P (2003) Narp and NP1 form heterocomplexes that function in developmental and activity-dependent synaptic plasticity. Neuron 39:513-528.

Yap CC, Muto Y, Kishida H, Hashikawa T, Yano R (2003a) PKC regulates the $\delta 2$ glutamate receptor interaction with S-SCAM/ MAGI-2 protein. Biochem Biophys Res Commun 301:1122-1128.

Yap CC, Murate M, Kishigami S, Muto Y, Kishida H, Hashikawa T, Yano R (2003b) Adaptor protein complex-4 (AP-4) is expressed in the central nervous system neurons and interacts with glutamate receptor $\delta 2$. Mol Cell Neurosci 24:283-295.

Yu X, Malenka RC (2003) Beta-catenin is critical for dendritic morphogenesis. Nat Neurosci 6:1169-1177.

Yudowski GA, Puthenveedu MA, Leonoudakis D, Panicker S, Thorn KS, Beattie EC, von Zastrow M (2007) Real-time imaging of dis- 
crete exocytic events mediating surface delivery of AMPA receptors. J Neurosci 27:11112-11121.

Yue Z, Horton A, Bravin M, DeJager PL, Selimi F, Heintz N (2002) A novel protein complex linking the $\delta 2$ glutamate receptor and autophagy: implications for neurodegeneration in lurcher mice. Neuron 35:921-933.

Yuzaki M (2003) The $\delta 2$ glutamate receptor: 10 years later. Neurosci Res 46:11-22

Zamanillo D, Sprengel R, Hvalby O, Jensen V, Burnashev N, Rozov A, Kaiser KM, Koster HJ, Borchardt T, Worley P, Lubke J, Frotscher M, Kelly PH, Sommer B, Andersen P, Seeburg PH,
Sakmann B (1999) Importance of AMPA receptors for hippocampal synaptic plasticity but not for spatial learning. Science 284:1805-1811.

Zhu JJ, Esteban JA, Hayashi Y, Malinow R (2000) Postnatal synaptic potentiation: delivery of GluR4-containing AMPA receptors by spontaneous activity. Nat Neurosci 3:1098-1106.

Zhu JJ, Qin Y, Zhao M, Van Aelst L, Malinow R (2002) Ras and Rap control AMPA receptor trafficking during synaptic plasticity. Cell 110:443-455.

Ziff EB (2007) TARPs and the AMPA receptor trafficking paradox. Neuron 53:627-633. 